\title{
Panamerican Trauma Society: The First Three Decades
}

\author{
${ }^{1}$ Rao R Ivatury, ${ }^{2}$ Michel Aboutanos
}

\begin{abstract}
Panamerican Trauma Society was born 30 years ago with the mission of improving trauma care in the Americas by exchange of ideas and concepts and expanding knowledge of trauma and acute illness. The authors, immediate-past leaders of the organization, review the evolution of this assembly of diverse cultures and nationalities.
\end{abstract}

Keywords: History, Panamerican Trauma Society, Trauma Society.

How to cite this article: Ivatury RR, Aboutanos $M$. Panamerican Trauma Society: The First Three Decades. Panam J Trauma Crit Care Emerg Surg 2017;6(2):90-123.

Source of support: Nil

Conflict of interest: None

\section{INTRODUCTION}

The Panamerican Trauma Society (PTS) was born 30 years ago with the mission of improving Trauma Care in the Americas by promoting an exchange of ideas and concepts and expanding knowledge of trauma and acute illness. The authors, immediate past leaders of the organization, review the evolution of this assembly of diverse cultures and nationalities.

It has now been 30 years since the PTS was born. The three decades of its short existence have been quite eventful in the scenario of growing pains, adolescence, maturation, and accomplishments. It is an interesting tale of people of various languages, nationalities, backgrounds, and races coming together to improve the care for the critically injured and ill surgical patients in the hemisphere. It is a journey of international collaboration in global surgery and improvements in surgical

\footnotetext{
${ }^{1}$ Professor Emeritus, ${ }^{2}$ Professor

${ }^{1}$ Department of Surgery, VCU Medical Center Richmond VA, USA

${ }^{2}$ Department of Surgery, Director Acute Care Surgical Services VCU Medical Center Richmond, VA, USA

Corresponding Author: Rao R Ivatury, Professor Emeritus Department of Surgery, VCU Medical Center, W 15E, 1200 East Broad Street, Richmond, VA 23298, USA, e-mail: raoivatury@ gmail.com
}

care of low- and middle-income countries (LMIC). The scope has extended now to distant continents also.

The first author of this communication has had the privilege of participation in this great odyssey, first as a young surgeon and a charter member, climaxing to the last 6 years of executive directorship. The authors have just finished their official posts of executive director and immediate past President of the Society respectively. The objective of this report is to document the Society's journey from its infancy to the current status of adulthood. The intention is not in the least self-aggrandizement, but to weave the evolution of a multinational society in the current era of increased enthusiasm for issues of global surgery. It is a tribute for the many, many individual members, Board of Managers, Committees, and past Presidents, who collectively should be credited with the current standing of the Society. We sincerely hope that the members will read this history, proudly own the Society as their own, and inspire others to advance it further. This document may also serve as the baton for the in-coming generation and leadership.

\section{THE BIRTH}

The Panamerican Trauma Society (PTS) was conceived over a lunch, in a restaurant in Mexico City named "Hacienda Los Morales" in 1987, during a Mexican Red Cross symposium. It was an inspired thought of Dr Armando Baqueiro of Mexico, who proposed to create a Society with the mission of improving the management of trauma patients in the American Hemisphere: North, Central, and South; and consequently with the name PTS. The visionaries included Drs Baqueiro, Aurelio Rodriguez, Alejandro Grife, Garcia Morales "El Max," Gomez Palacio, Carlos Moreno, all Latin American surgeons of experience and repute (Fig. 1). Drs Aurelio Rodriguez and Francisco Holguin (from Colombia) traveled all through the Latin American world, presenting the proposition to create this Society. The idea met with unanimous approval. The Society was officially founded in Bogota, Colombia, in 1989. The first officers and members met during the Annual Congress of the Federation of Latin American Surgical Societies in Ecuador, and, at that time, Dr Aurelio Rodriguez from Peru and the USA was

This is an expanded version of the article published in the Journal of Trauma and Acute Care Surgery, 2017 May;82(5):966-973 under the open access license of CC-BY-NC-ND 


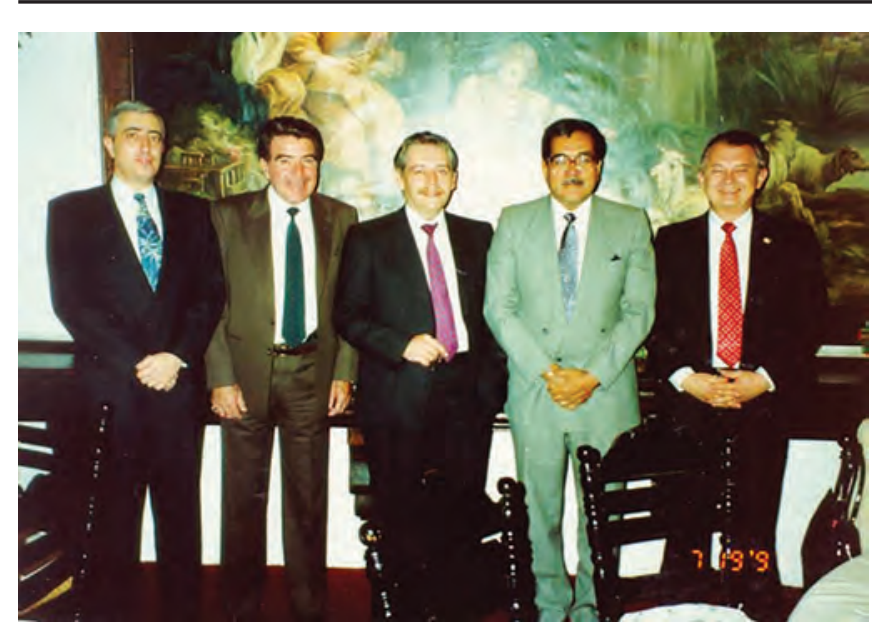

Fig. 1: The "lunch of inspiration" where the PTS was proposed From left to right: Drs Gomes-Palacios, Carlos Moreno, Armando Baqueiro, Aurelio Rodriguez, Alejandro Grife. Missing: Garcia Morales "el max"

appointed as the first president and Ricardo Sonneborn from Chile as the first vice president.

\section{INFANCY}

The first Annual Congress of the PTS was held in San Juan, Puerto Rico, in 1988, with economic benevolence of its governor. A further definition of the Board of Directors was accomplished. The second Congress was about to happen in 1989, in Puerto Rico. There was, however, an unwelcome intruder in the form of Hurricane Hugo. The Congress never materialized. Fortunately, both the Society and the stranded early visitors survived this adversity. The second scientific assembly of the Society was held the next year in São Paulo, Brazil. The Brazilian group, led by the distinguished Professor Dario Birolini and his group from Das Clinicas, joined the PTS. The Brazilian collaboration is strong to this day. The third Congress in Buenos Aires, Argentina followed the first assembly of a newly formed Association of Trauma of Colombia in Bogota, Colombia. Since that time, the PTS matured and a Congress was held annually each November in various countries (Table 1). The three major non-US members of the PTS, namely, Brazil, Colombia, and Argentina, and their delegates including Professors Birolini, Holguin, and Rasslan were the earliest pioneers. Strong North American support was lent by the early leaders: Professors Rodriguez, Mulder, and Ernest Moore. Professors Feliciano, Hoyt, Maull, Mattox, Maier, Frykberg, Baker, and Briggs from the USA, Gutiérrez and Neira from Argentina, Tovar from Mexico, and many others served to mature the PTS. The PTS annual congresses gained an international reputation with the participation of leading health professionals in Trauma and Critical Care from around the world. The Society celebrated its silver (25th) anniversary in 2015 in Medellin,
Table 1: Annual meetings
1987 First Board Meeting, Quito
1990 São Paulo, Brazil
1991 Buenos Aires, Argentina
1992 Guadalajara, Mexico
1993 Costa Rica
1994 Cartagena, Colombia
1995 Salvador, Brazil
1996 Cartagena, Colombia
1997 Miami, USA
1998 Buenos Aires, Argentina
1999 Panama
2000 Margarita, Venezuela
2001 Monterrey, Mexico
2002 São Paolo, Brazil
2003 Lima, Peru
2004 Miami, USA
2005 Guayaquil, Ecuador
2006 Cartagena, Colombia
2007 Puebla, Mexico
2008 Campinas, Brazil
2009 Caracas, Venezuela
2010 Montevideo, Uruguay
2011 Asuncion, Paraguay
2012 Medellin, Colombia
2013 Santiago, Chile
2014 Panama City, Panama
2015 Santra Cruz, Bolivia
2016 Maceio, Brazil

1988 First PTS congress, Puerto Rico

Colombia, in a proud display of science and culture, with most of the Presidents in attendance. The participation, as has become usual with the PTS, involved not only surgeons, but also emergency physicians, internists, nurses, paramedics, residents, and medical students. The PTS just finished a successful joint Congress with the Sociedade Brasileira de Atendimento Integrado ao Traumatizado (SBAIT) in Maceio, Brazil, in 2016.

\section{OFFICERS OF PTS}

As the Society was growing out of its infancy, the multinational and multicultural diversity of the organization became a prominent pillar of strength and a universally admired trait. All countries of South America and their existent trauma and surgical organizations began to participate and contribute to the shared mission of the Society. Where none existed, there was a new enthusiasm to form local organizations and join the PTS. Very early on, the Society decided to alternate the Presidency between distinguished North American and South American surgeons, and the tradition lives on today (Annex 1 and Fig. 2). 
Annex 1: Annual Congresses, Presidents, and Aurelio Rodriguez Lecturers

\begin{tabular}{|c|c|c|c|c|}
\hline Year & City & President & Aurelio Rodriguez Lecturer & Topic: Aurelio Rodriguez Lecturer \\
\hline 1988 & San Juan, Puerto Rico & A Rodriguez (USA) & & \\
\hline 1990 & São Paulo, Brazil & A Rodriguez (USA) & & \\
\hline 1991 & Buenos Aires, Argentina & F Holguin (Colombia) & & \\
\hline 1992 & Guadalajara, Mexico & E Moore (USA) & & \\
\hline 1993 & San Jose, Costa Rica & D Birolini (Brazil) & & \\
\hline 1994 & $\begin{array}{l}\text { Cartagena de Indias, } \\
\text { Colombia }\end{array}$ & C Lucas (USA) & & \\
\hline 1995 & Salvador, Brazil & A Baqueiro (Mexico) & & \\
\hline 1996 & $\begin{array}{l}\text { Cartagena de Indias, } \\
\text { Colombia }\end{array}$ & K Maull (USA) & & \\
\hline 1997 & Miami, USA & R Ferrada (Colombia) & & \\
\hline 1998 & Buenos Aires, Argentina & G Gomez (USA) & & \\
\hline 1999 & Isla Margarita, Venezuela & D Ortega (Peru) & & \\
\hline 2000 & Ciudad de Panama, Panama & D Feliciano (USA) & & \\
\hline 2001 & Monterrey, Mexico & J Neira (Argentina) & & \\
\hline 2002 & São Paulo, Brazil & R Ivatury (USA) & Ricardo Ferrada (Colombia) & Education and trauma \\
\hline 2003 & Lima, Peru & S Rasslan (Brazil) & Gerardo Gomez (USA/Venezuela) & Sepsis, what is new? \\
\hline 2004 & Miami, USA & S Briggs (USA) & Donald Trunkey (USA) & $\begin{array}{l}\text { Violencia, Drogas y Trauma en el } \\
\text { Hemisferio } \\
\text { Occidental: Una solución } \\
\text { alternativa. }\end{array}$ \\
\hline 2005 & Guayaquil, Ecuador & J Lombardi (Chile) & Ernest Moore (USA) & Blood substitutes in trauma \\
\hline 2006 & $\begin{array}{l}\text { Cartagena de Indias, } \\
\text { Colombia }\end{array}$ & D Hoyt (USA) & C Willam Schwab (USA) & The winds of war \\
\hline 2007 & Puebla, Mexico & C Morales (Colombia) & Jorge Neira (Argentina) & $\begin{array}{l}\text { Nuevos aspectos en la } \\
\text { resucitación de volumen en la } \\
\text { atención inicial del paciente } \\
\text { traumatizado }\end{array}$ \\
\hline 2008 & Campinas, Brazil & A Peitzman (USA) & Raul Coimbra (USA/Brazil) & $\begin{array}{l}\text { Trauma as a disease: The } \\
\text { public's perception }\end{array}$ \\
\hline 2009 & Caracas, Venezuela & J Garcia (Venezuela) & Renato S Poggetti (Brazil) & Trauma prevention \\
\hline 2010 & Montevideo, Uruguay & R Coimbra (USA) & Ronald Maier (USA) & $\begin{array}{l}\text { Molecular and genetic aspects of } \\
\text { the response to trauma }\end{array}$ \\
\hline 2011 & Asuncion, Paraguay & R Pogetti (Brazil) & Armando Baqueiro (Mexico) & $\begin{array}{l}\text { The evolution of teaching and } \\
\text { management of trauma in Mexico } \\
\text { in the last } 25 \text { years }\end{array}$ \\
\hline 2012 & Medellin, Colombia & J Puyana (USA) & Ethan Nadelmann (USA) & $\begin{array}{l}\text { Why we need to end the war on } \\
\text { drugs }\end{array}$ \\
\hline 2013 & Santiago, Chile & A Pacheco (Chile) & Ricardo Sonneborm (Chile) & Origin and destination in trauma \\
\hline 2014 & Panama City, Panama & M Lorenzo (USA) & Stanley Motta (Panama) & $\begin{array}{l}\text { Why trauma? A personal } \\
\text { experience }\end{array}$ \\
\hline 2015 & Santa Cruz, Bolivia & G Fraga (Brazil) & Rao Ivatury (USA) & PTS: A look back and a look forward \\
\hline 2016 & Maceio, Brazil & M Aboutanos (USA) & Thomas Scalea (USA) & $\begin{array}{l}\text { Mentoring the future trauma } \\
\text { leaders: Implications for the } \\
\text { Panamerican Trauma Society }\end{array}$ \\
\hline
\end{tabular}

Each of these leaders, over the past three decades, reinforced the common mission, emphasized our identity among diversity, defined future goals for the Society, and inspired continued growth. The Presidents are assisted in their duties and responsibilities by an Executive Director. These two highest officers of the organization and their close partnership have been an essential recipe for the success of the Society. The persons who have had the privilege of this position are Doctors Rodriguez, Holguin, Gomez, Maull, Peitzman, and Ivatury. Doctor Scalea is the newly elected Executive Director and has taken charge since November of 2016. With a Board of Directors that was young and eager, and a Secretary-Treasurer of indefatigable enthusiasm and energy, the PTS made rapid strides in recruiting members and keeping the momentum flowing. Doctors Barba, Gomez, Peitzman, Puyana, and Aboutanos deserve immense credit for their tireless efforts as Secretary-Treasurers in bringing the Society to the 21st century. The current Secretary, Dr Esteban Foainini, is following their eminent example. 

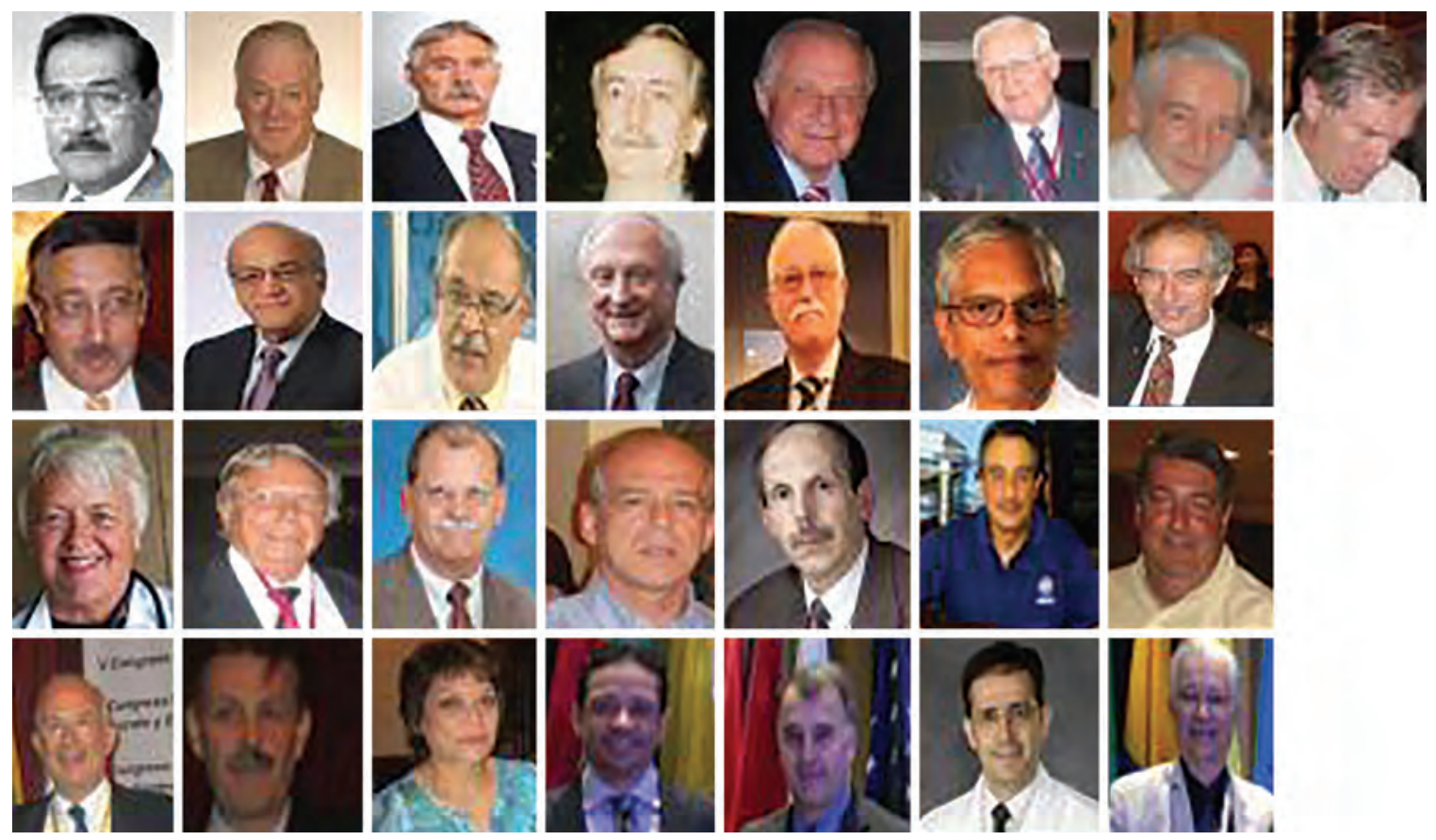

Fig. 2: Presidents of PTS

Row 1 (Left to Right): A Rodriguez (USA), 1987 to 1989; D Mulder (Canada), 1989 to 1990; E Moore (USA), 1990 to 1991; F Holguin (Colombia), 1991 to 1992, D Birolini (Brazil), 1992 to 1993; C Lucas (USA), 1993 to 1994; A Baqueiro (Mexico), 1994 to 1995; K Maull (USA), 1995 to 1996

Row 2 (Left to Right): R Ferrada (Colombia), 1996 to 1997; G Gomez (USA) 1997 to 1998, D Ortega (Peru); 1998 to 1999; D Feliciano (USA), 1999 to 2000; J Neira (Argentina), 2000 to 2001; R Ivatury (USA) 2001 to 2002; S Rasslan (Brazil), 2002 to 2003

Row 3 (Left to Right): S Briggs (USA), 2003 to 2004; J Lombardi (Chile) 2004 to 2005; D Hoyt (USA) 2005 to 2006; C Morales (Colombia) 2006 to 2007; A Peitzman (USA) 2007 to 2008; J Garcia (Venezuela), 2008 to 2009; R Coimbra (USA), 2009 to 2010

Row 4 (Left to Right): R Pogetti (Brazil) 2010 to 2011; J Puyana (USA) 2011 to 2012; A Pacheco (Chile) 2012 to 2013; M Lorenzo (USA) 2013 to 2014; G Fraga (Brazil) 2014 to 2015; M Aboutanos (USA) 2015 to 2016, C Ordonez (Colombia) 2016 to 2017

\section{OFFICES OF PTS}

Initially located in Baltimore, thanks to the support from Dr RA Cowley at The Shock Trauma Center, the offices moved to Connecticut with a new secretary. The year 2003 was a significant game-changer when Dr Peitzman took the Society to the University of Pittsburgh and nurtured it for the next 7 years. Under the leadership of Drs Peitzman (as a Secretary, President, and Executive Director) and Puyana (as a Secretary, and then as President), the PTS saw tremendous advances in membership recruitment, record keeping, streamlining of PTS educational courses, as well as updating the Society website.

On November 12, 2010, the headquarters office was moved from Pittsburgh to the current location in Richmond, at the Division of Acute Care Surgical Services, Department of Surgery, Virginia Commonwealth University (VCU) with an excellent administrator, Ms Gladys Soruco Shanklin. The PTS and VCU, under the benevolence of President Michael Rao and Dean Jerry Strauss MD, entered into a partnership, with the university providing significant financial assistance to the PTS office and its staff, and providing Continuing Medical Education (CME) for PTS congresses. The VCU President, Dean, and Department Chairs of Surgery, Doctors Neifeld and Kasirajan, attended the PTS Congresses in 2012 and 2015, and bonded this relationship. In 2016, the VCU School of Medicine formally signed a Memorandum of Understanding with the PTS for continued financial support of more than $250 \mathrm{~K}$ annually, committed for another 3 years.

\section{MATURATION OF THE VISION OF PTS}

Over the past decade, the PTS matured and entered adulthood. Where it was previously a clinically focused organization, it has now attained a trauma systemoriented focus. Where once it was a Congress-centered Society, it has now become a Society with a Congress. It was a nomad Society with frequent migrations, but is now a university-based Society. In this maturation process, it has set a path to achieve financial independence and become solvent. The following narrative will attempt to illustrate some of this progress. 


\section{Membership Services}

As of 2015, the Society membership has reached 27 countries (21 Latin American and Caribbean: Argentina, Bolivia, Brazil, Canada, Chile, Colombia, Costa Rica, Cuba, Curacao, Dominican Republic, Ecuador, El Salvador, Guatemala, Mexico, Nicaragua, Panama, Paraguay, Peru, the USA, Uruguay, Venezuela; and 6 other countries: Angola, Finland, Qatar, Netherland, Norway, and Spain). Active efforts are underway to increase the membership from the initiative of committee chair Dr Maria F Jimenez.

\section{PTS Website}

The PTS saw significant advances in its website development under the leadership of Drs Peitzman and Puyana (2003-2010). With the relocation of the PTS headquarters to Richmond, Virginia in 2010, a crucial decision was made to set the PTS website independent of a University server and its obligatory firewalls. This allowed for an exponential advancement in the functionality of the website to serve the members of PTS. It provided an automated toggle system between its three languages (English, Spanish, and Portuguese); an automated communication system (2011); an automated online payment system (2012); and an automated online research competition and abstract submission and evaluation system (2013). A. Vimeo-based video hosting and sharing platform (2014) was developed with the help of ex vice president Daniel Ludi. This last feature makes available the myriad of lectures from leading experts on trauma and emergency care. Online $\mathrm{CME}$, a mobile device display, news center, and social media links (2015-2016) were recent enhancements.

\section{The Educational Agenda of the PTS}

The shared mission of the members of the PTS is to improve the care of the critically ill or injured patients in the Americas, especially in South America. The Society aims to achieve this by its constant emphasis on CME and collaboration, with an energized education committee under the direction of Dr Paula Ferrada.

The PTS believes that improvements in the care of the injured or ill patient, even in those countries with limited resources as in LMIC, are feasible and depend on organization and planning. It argues that education and practice-based learning through all of its courses will have a positive impact on patient management. The courses totaled to 136 from 2010 to 2015, many of them through SBAIT. They included surgical skills in trauma (DQT), ultrasound in emergency and trauma (USET) basic, USET advanced, advanced disaster medical response (ADMR) course, World Health Organization
(WHO)-quality improvement course, basic trauma course for rural physicians/nurses/prehospital staff, burn course, nursing course, air medical rescue course, and prehospital course, among others. These courses are standardized and propagated by using information technology (web-based) and also social media. The demand for these courses is increasing throughout Latin America, as they are designed especially for the professionals and health care providers in LMIC and are more affordable than the European or American courses.

\section{The Aurelio Rodriguez Lecture}

Started in 2002, and given at the annual Congress by invitation from the President, it was created to honor the founder, visionary, and leader of the PTS. It is a tribute for his presence, contributions, and participation that provide the "glue" to keep the society united. The lecture, on a contemporary topic, soon became a highlight of the Congress and is greatly valued by both the lecturer and the audience. These are listed in Annex 1.

\section{Involvement of Local Societies}

The next initiative by the PTS is to involve local societies and help them organize educational activities, offering them PTS courses at reduced prices and providing help with faculty and materials. The PTS also acts as the parent organization to several trauma-focused organizations in Mexico, Ecuador, Colombia, Panama, Bolivia, Peru, Paraguay, Uruguay, Brazil, and Argentina.

\section{Exhibition of Research and Publications from South America}

It is well known that care of injury and surgical illness is overwhelmingly complex in its incidence and severity in these countries, even as the South Americans are recognized for their immense wealth of experience in these fields. Besides the adroit surgical skills that this experience brings them, they have developed many innovative, low-cost solutions in their clinical practice befitting their own economic conditions. Prime examples include the Borraez (Bogota) bag for temporary abdominal closure from Colombia, the Pogetti pack (for internal compression of missile tracts of the liver) from Brazil, and the first endovascular abdominal aortic aneurysm repair (Parodi, Buenos Aires). Many such exciting developments take place every day in South America, and the PTS provides these innovators an avenue to showcase their talents in Congresses and publications (the official journal of the Society, textbooks, etc.)

Held annually in the PTS Congress for attendings, residents and students have witnessed tremendous growth in the abstracts submitted to the Congress over the 




Graph 1: Number of abstract submissions for the annual congress 2010 to 2016

past 5 years (Graph 1). There were a record 900 abstracts in 2016, leading to the Congress presentations of 80 oral and 313 mini-oral presentations. One entire session was dedicated to injury prevention.

Coincidentally, the number of manuscript submissions to the Society's journal, The Panamerican Journal of Trauma, Critical Care and Emergency Surgery (PAJTCCES) has expanded with a steady, noticeable improvement in quality.

Traveling scholarships for the winning abstracts are donations provided by past President Dr Susan Briggs related to disaster management and in the area of injury prevention, past President Dr Michel Aboutanos and Dr Terrence O'Keefe: Shining examples of inspiration. Impressively, the current President Dr Carlos Ordonez and his team from Cali have excelled in successfully placing their abstracts in the extremely competitive oral presentations of the annual scientific meeting of the American Association of the Surgery of Trauma (AAST). Their recent record of multiple publications in international journals has set new standards for the PTS.

\section{Publications of the PTS}

The PTS is active in publishing textbooks, manuals, and guides by its members. Many of them have been transferred to PTS ownership. Examples include: TRAUMA (the official textbook of the PTS, currently undergoing a revision with a new edition which will be available in both print and an e-book, expected in 2017); Guidelines for Trauma Quality Improvement Programs (along with the WHO) in English and Portuguese; Manuals of USET Advanced in Spanish; USET and ADRM - Portuguese and Spanish; Burn (Quemados) - Spanish. Others published by PTS members were translated into Spanish, i.e., Abdominal Compartment Syndrome; Trauma Manual;
US in the ICU; Cuidado Intensivo y Trauma, and the Guidelines for the development of trauma systems and essential trauma care for Latin America (Vega et al).

\section{Journal}

The PTS has long maintained its own journal, the Panamerican Journal of Trauma, under the editorship of Doctor Ricardo Ferrada. After a hiatus in 2009, the journal was resumed in 2012, with a new editorial board under the editorship of Dr Rao Ivatury and Jaypee publishers from India. Published quarterly as an e-publication, it covers all aspects of trauma, critical care, and emergency surgery. It aspires to be a vehicle for all PTS members to showcase their vast clinical experience and appears to be succeeding in this mission. More importantly, it has become a resource for the younger generation of medical students, residents, and junior faculty surgeons in their efforts at initiating scientific reporting. It has also become a conduit for publication of papers presented in research competitions at the annual Congress. The editorial board promises to continue to attract clinical research based on the plentiful material that the PTS members are provided with, and also promises to continue encouraging young surgeons and trainees to publish. Medline indexing by the National Library of Medicine is a vital goal that hopefully can be reached this year.

\section{International Tele-grand Rounds}

Dr Antonio Marttos and the University of Miami/Ryder Trauma Center established the International Trauma Tele-Grand Rounds, weekly case presentations telecast and discussed by trauma surgeons around the world. Through videoconferencing, complex trauma case presentations and advanced trauma and critical care topics are discussed on a weekly basis. Case presentations provide students, residents, fellows, and attending physicians with an outstanding tool for education and sharing of medical expertise across borders. The CME credits are available to eligible physicians. To date, there have been 42 participating institutions, including the USA, Brazil, Colombia, Bahamas, Haiti, Canada, Venezuela, Argentina, Panama, Puerto Rico, Dominican Republic, British Virgin Islands, Spain, Thailand, Turkey, and Iraq; ranging from academic medical centers to urban trauma centers, military, community, and rural hospitals. ${ }^{1,2}$ The PTS has adopted the Tele-Grand Rounds as one of their educational activities. In an academic agreement, these conferences are advertised on the AAST website for their information and participation. Efforts are under way to convert some of these into full-fledged publications in the Journal of Trauma and Acute Care Surgery. 


\section{International Fellowships and Scholarships}

The PTS became involved in facilitating opportunities for young residents-in-training as well as junior surgeons to make use of the tremendous clinical material available in South and Central America and the science and art of trauma systems in the USA., ${ }^{3,4}$ The objective of the fellowship is to improve surgical training for traveling fellows and bring opportunities to the host institution to experience research and exchange.

North American scholars are benefited by coordinating their visit to a center of excellence in South or Central America, with a local expert hosting the visit, and the PTS providing options for housing, necessary travel details, and logistics. Some recent winners of this international scholarship include residents from East Carolina University, University of Miami, Emory University, and Indiana University. Other examples include a traveling Fellow to Bolivia to work on the PTS Trauma Registry (described below), or traveling for training in Ultrasound in Cuba. These International Fellowship opportunities received their funding from generous donations from individual members (like Paula Ferrada MD), and the Postgraduate Fellowship in Global Health at Northwestern University Feinberg, SOM's Center for Global Health under the guidance of Dr Mamta Swaroop.

In return, the host institutions in the Latin region develop relationships with North American institutions, providing networking opportunities and fostering collaborative research and programs. The North American institutions provide the PTS International Observership Program described below, as well as an international research scholarship. This scholarship aims to provide aspiring trauma surgeon-scientists from the Latin Region the opportunity for training in health services research and professional development at the North American institutions. Examples include a traveling Fellow to Bolivia, traveling for training in Ultrasound in Cuba, a research Fellow at The Center for Surgery and Public Health (CSPH) at Brigham and Women's Hospital under the mentorship of Dr Adil Haider, with a focus on functional Outcomes and Recovery after Trauma Emergencies.

Short-term rotations (3-6 weeks) are also available to South American physicians, nurses, paramedics, and students to visit trauma centers in the USA to observe, audit, and experience trauma system development and operations, nuances of quality improvement activities, and team development and management in the care of the injured or critically ill surgical patients. This International Observership Program is open for qualified foreign national members, who wish to visit and observe certain clinical and educational activities of affiliated trauma centers. Just at VCU alone, a total of 19 observers (from general practitioners to trauma fellows) made use of this opportunity, visiting from countries like Colombia, Brazil, Mexico, Chile, Ecuador, and Sudan.

Other centers, such as the University of Pittsburgh Medical Center and Alleghany Medical Center (Pennsylvania), Riverside County Regional Medical Center (California) and University of San Diego, Indiana University and University of Southern California are also actively involved. The PTS and its 18 affiliated societies and universities, such as "Universidad del Valle" (Valle University) in Cali, Colombia, offer notable examples. Since 2011, their fellows in Trauma and Acute Care Surgery have had the opportunity to do a 3 month internship at VCU and also at the University of Pittsburgh.

In the past, many trauma fellows from $\mathrm{R}$ Adams Cowley Shock Trauma Center in Baltimore, Maryland, as well as fellows from Israel and other parts of the world spent 1 month under the tutelage of Dr Ricardo Ferrada at Cali, Colombia, for an enormous experience of challenging trauma cases. Glowing testimonials of this experience were reported by Knuth, Ferrada, and others..$^{5-7}$

\section{Paramedic Exchange Program}

Emphasis on prehospital care, training, and development in the Latin American region became an important mission of the society, and so we created a dedicated prehospital subcommittee, prehospital courses, prehospital sessions at the annual congress, and the Paramedic Exchange program. In 2014, The Virginia Association of Volunteer Rescue Squads (VAVRS) and PTS, under the leadership of Jane Laverne (USA) and PTS prehospital committee Chair, Dr Andres Rubiano, developed a Prehospital Exchange Program between prehospital personnel of the state of Virginia and the prehospital personnel of various cities from Colombia. The result was a reciprocal exchange of paramedics who shared invaluable first-hand knowledge and experience and tactful training in emergency response in both high and LMIC settings. These exchanges were further enhanced by dedicated short-term rotations with Richmond Ambulance Authority and the Virginia State Office of EMS.

\section{Nursing Education}

From the outset, the PTS has given enormous respect to the nursing field, recognizing it as an important member of the team. Early pioneers of the nursing section of the PTS, such as Mary Beachley form the Maryland Institute of Medical Sciences and Vivian Lane from Connecticut held successful educational activities for nurses during PTS Congresses. Cristiane de Alencar Domingues from São Paulo is leading the nursing component of the PTS with energy and enthusiasm. 
The PTS, along with Rutgers Robert Wood Johnson Medical School, Rutgers School of Nursing, and Robert Wood Johnson University Hospital (RWJUH), supported by a grant from Rutgers Centers for Global Advancement and International Affairs (GAIA Centers), hosted a global nursing symposium in New Jersey, USA, in June 2016, under the leadership of Dr Peck. Consuelo Burbano from Cali, Colombia's University de Valle, and Lisa Falcon and Sue Willard from Rutgers University provided a broad overview of trauma systems concepts, specifically focusing on the development of a Trauma Nurse Manager role. The PTS effort, led by Cristiane de Alencar Domingues, Gaspar Reboredo, and Jasmine Garces, organized Trauma Nursing Courses for six nursing participants from Kenya and Colombia during the symposium. This is a prime example of academic partnerships between high-income US universities that share with the PTS common surgical care missions in Latin America. The 2017 symposium is currently being planned for the month of March.

\section{Trauma Leagues}

Academic Leagues have emerged in Brazil as a teaching experience in the early 1990s, consisting of student associations under the mentorship of a supervising teacher. Started by Dr Mario Mantovani in Campinas, Brazil, and nurtured by past President of the PTS, Gustavo Fraga, Trauma League from UNICAMP (University of Campinas), UNICAMP, and another 9 Trauma Leagues in 1999 formed Congresso Brasileiro das Ligas do Trauma (CoBRaLT), the largest of the Trauma Leagues. They focus on trauma concepts and emergency care, and expose students to the ED, OR, and prehospital areas and also stimulate an interest in Trauma as a career. ${ }^{8}$ The CoBRaLT is the central committee of all Trauma Leagues in Brazil, representing and coordinating them in all aspects of Trauma and Emergency Surgery. It organizes the annual congress of the Brazilian Congress of Trauma Leagues, bringing together more than 800 medical students from different schools. Similar leagues have been started in the USA (Pittsburgh, Richmond).

In 2013, the first Ecuadorian Trauma and Emergency League (LATE) was created with the support of two universities; Universidad del Azuay and Universidad de Cuenca, in the city of Cuenca, Ecuador. This coincided with the inauguration of a brand new Emergency Medical Service (SIS ECU 911) and the development of new technology of the Trauma and Emergency Center of Hospital Vicente Corral Moscoso (HVCM). In 2013, LATE had 40 students and 4 tutors working on four main areas: Prevention and promotion in the trauma field, medial education, investigation, and a discipline and control committee. The excitement of LATE was evidenced by the number of students who wanted to belong (113 in 2013 and 400 in 2014). Only 45 and 42 were admitted respectively! The current membership totals 80 - who were responsible for 28 successful projects, including suture and anesthetic block workshop and First Aid in Trauma, basic trauma course of PTS, "Respect to 911 call" to prevent false calls to the EMS, and "become a blood donor," educating high-school students about the first responder role (612 students). Other accomplishments included outreach to nearly 5,000 people, 5 publications, 16 training courses, 14 promotion campaigns, 10 oral presentations, 3 PTS international travel grants $(2014,2015$, and 2016); first place oral presentation in the 2013 PTS Congress in Panama and 20 research projects (17 completed).

Colombia is the latest country seeing the rise of Trauma Leagues titled Liga de Trauma y Emergencias del Pacifico. They are located in Cali under the guidance of Fundación Valle de Lili and current President of the PTS, Dr Carlos Ordonez. It has more than 50 medical students, all of them members of the PTS.

The student body of the Trauma Leagues is growing not only in numbers, but also in participation in local and international Congresses with improving quality of academic participation. Admittedly, Trauma Leagues are not an original PTS initiative. Many of the Leagues and international student organizations, however, are members of the PTS and now find their international meeting ground and networking at the PTS annual Congress.

The PTS has its own student section with an administrative structure that involves the membership of various countries. They have been very active in the past Congresses of the Society, conducting their own scientific program with the help and participation of senior members of the Society.

The PTS is proudly involved in carrying the great movement of the youth forward and creating robust opportunities for its escalation.

\section{REGISTRY}

Changing the trajectory of the colossal casualty of trauma requires preventative strategies informed by injury surveillance and risk factor identification. A lack of reliable data leaves the magnitude of the injury problem largely unknown in many LMICs. Trauma Registries promise to fill this void by capturing important information about the continuum of the patients' care, as well as serving as a tool to oversee quality of care. Despite widespread recognition of the value of trauma Registries and their extensive adoption in developed countries, only 50 registries across 21 LMICs are documented in the literature. ${ }^{9}$ This enormous burden of injury in the LMIC needs to be defined in its nature and magnitude. It substantiates the 
words of Margaret Chan, Director General of WHO, “... the real need (in global health) is to close the data gaps, especially in low and middle-income countries, so that we no longer have to rely heavily on statistical modelling for data on disease burden." 10

The PTS, with assistance from the International Trauma System Development Program (ITSDP) at VCU, has been a pioneer in this field having developed a Trauma Registry for this purpose. Initial implementation in countries, such as Ecuador, Colombia, and Panama, has led to collection of sizable data and many analytical reports from these countries. Examples include 15 publications (9 published in the journal of the Society) about the registry and with data from the registry of the PTS collected from "Hospital Universitario del Valle" (the largest university hospital of the southwest region of Colombia) and "Fundación Valle del Lili" (the largest level I trauma center of the southwest region of Colombia). ${ }^{11-14}$

Recent advancements to the initial versions of the registry have been impressive: Availability of desktop and laptop versions, mobile friendly and scalable design, and compatibility with multiple devices, such as smartphones, iPads, and other tablets. The modular system and database design allow speedy customization. Logical grouping of elements allows turning on and off of elements at the tier level. Prehospital tier captures a total of 22 data points, essential elements tier captures 27 data elements corresponding to the minimum number of data points needed to support a trauma quality program, and tier 2 includes additional elements and ICD 10 coding. A full registry has 250 data elements for comprehensive capture of injury data at various levels of health facilities (basic, general hospitals, definitive referral centers). The ITSDP undertakes the set-up, implementation, and roll-out of the registry in interested countries. It is poised to become more widespread. Eventual progression to a Panamerican Trauma Data Bank is a hopeful outcome.

\section{INTERNATIONAL COLLABORATION}

The PTS has been continually pursuing collaboration with international trauma organizations and societies. In the past 5 years, collaboration was established with the Trauma Association of Canada, the Eastern Association for the Surgery of Trauma, the World Society of Emergency Surgery, and the Trauma Center Association of America. In 2012, the PTS co-organized the World Trauma Congress, in Rio de Janeiro, with 3,500 attendees, and that same year, it became a member of the World Trauma Coalition and participated in the two world Congresses: Frankfurt in 2014 and New Delhi in 2016. In 2013, the PTS became an official member of the World Health Organization's Global Alliance for the Care of the Injured. Most notably, an MOU with the AAST was completed in 2016, in areas of international exchange of fellows and scholars and international Grand Rounds.

Apart from individual Societies, multiple MOUs were signed with individual academic centers that further the mission of the Society. These include MOUs with the University of Miami for international grand rounds, the University of Seattle to develop an online QI platform, VCU to develop the PTS registry, and the University of Azuay and the Ecuadorian National Network for Research and Education (CEDIA) for the development of an electronic platform for Essential Trauma Care Guidelines (EsTC) for trauma center site evaluation and verification in the Latin Region - tactful steps in the development of tools for trauma system development in the Latin Region. The EsTC platform was field tested in 2015 in Bolivia for a site evaluation of two large urban hospitals for verification of their resources and capabilities to care for the injured. The impact and development of these basic tools can, with minor adjustments, be applicable in other LMIC: An MOU with the Sri Venkateswara Medical Institute of Tirupathi (SVIMS) in Andhra Pradesh, South India was just signed to implement trauma care and trauma education in that State.

\section{INJURY AND VIOLENCE PREVENTION}

Essential to the new direction of PTS to address systems of trauma care, injury prevention became an integral component of the society's mission. Initial sporadic lectures in the PTS Congresses prior to 2010 have evolved to the development of a PTS injury and violence prevention committee in 2012, and an Injury and Violence Travel Scholarship in 2013. Most notably, a dedicated injury prevention research competition was launched in 2016, highlighting 20 podium presentations from the USA, Brazil, Argentina, Venezuela, Ecuador, and Colombia. In 2014, past President Gustavo Fraga inspired PTS in joining the International Yellow May movement, initiated in Brazil, to promote global awareness of road traffic injuries and the importance of their prevention. Additionally, in 2015 an MOU was established with the US-based National Network of Hospital Based Violence Intervention Programs (NNHVIP) to promote international initiatives and collaborative program development. Finally, the presidential address by M. Aboutanos in 2016 called to action for the PTS to develop tools for Hospital Community-based injury and violence prevention that included (1) essential guidelines for injury prevention program development; (2) regional injury prevention database integrated with the PTS registry; (3) guides for hospital-based intervention research and grants; and (4) integrated platform for site evaluations. 


\section{SUMMARY}

The PTS has entered its fourth decade with many accomplishments, having survived considerable challenges. It exemplifies the anatomy of a successful society, created for a unified reason: To do things of value and worth that can be done better together. The PTS leadership appreciates this distinguishing characteristic. The PTS is led by policy and strategy, and not by the personality of the moment. ${ }^{15}$ It exhibits a coherency in the pursuit of what really matters, its stated mission. The Society's Presidents have consistently given their members a message of unity among diversity "see the value of the membership, the importance of attending our annual meeting, and the opportunity to get involved in the business of the society" - R. Coimbra, 2010; "We need to: Broaden the official participation of Trauma Society Boards of different countries in PTS ... organize Trauma Societies in the American countries without one and promulgate existing trauma courses, ... to integrate actions and exchange experiences between PTS and regional Trauma Societies without losing our identity" - R. Poggetti, 2011-; "The future of the PTS is promising; .... The scientific program is of high quality" - JC Puyana, 2012; “... The Society has grown into a strong and relevant force in the development of educational courses, prevention programs, publications, and scientific research forums that improve trauma management ..." - M. Lorenzo, 2014. Finally M. Aboutanos, immediate past President of the PTS, defined for us the next frontier: "Equally, we cannot talk about systems, if our society is not involved in creating and advancing the very tools that create the system including data registries and management as well as pre-hospital and hospital quality improvement initiatives ...."16

The PTS has come a long way in cohort with its family societies: A melting pot of different races, cultures, and nationalities with a shared dream and mission. Undoubtedly, it has improved patient care by an interchange of ideas and expertise, expanding the scope of practice beyond injury to critical illness. Through educational courses, international fellowships, and observerships, it engaged its youth. It stimulated interest in our specialty and kindled flames of curiosity and leadership in them. It showcased the vast South American trauma experience and the innate adroit surgical ability of Latin American surgeons. It created new paradigms applicable to these countries. It initiated injury prevention strategies. It is on the verge of addressing system issues.

It is crucial that the PTS looks ahead to the future and faces the challenges that inevitably lurk around the corner. Uncertainty, change, and risk are a given. Dealing with complexity involves active receptivity, clarity, openness, and consensus. Where should the PTS be in a decade or so? What work needs be done, who should be doing what? Is what is being done working? There are pragmatic questions that the new leadership and the Society need to face and answer strategically: What is the PTS? Is it a collection of different local societies, or is it an integrated family, where the societies are willing to lose their identity for the greater prize? Is it truly "Panamerican?" Is there a need to "cut the cord," as some have suggested? It is very presumptuous and conceited to think one part of our society is a "cord" of nourishment to the other!

In closing, we humbly propose that it is imperative for the PTS to appreciate that in this increasingly complex system, order flows from interactions, not from central control. It should continue to emphasize the small positive actions from the membership body to benefit from these interactions and adaptations. Playing on the global stage, sharing problems, seeking collaboration and creating partnerships is, undoubtedly, the apposite strategy.

\section{ACKNOWLEDGMENTS}

The authors gratefully salute Presidents, Committees, and members of PTS for their dedication and labor of love in carrying the Society forward; Ms Gladys Soruco Shanklin for her superb coordination of PTS office; Drs Lucas, Fraga, Morales, Neira, Peitzman, Maull, Fraga, Baqueiro and Peck for their historic notes; Dr Rodriguez for his vision, support, and review of the manuscript; and the Executive Committee of the PTS for their review and valuable suggestions.

\section{REFERENCES}

1. Marttos AC, Kuchkarian FM, Abreu-Reis P, Pereira BM, Collet-Silva FS, Fraga GP. Enhancing trauma education worldwide through telemedicine. World J Emerg Surg 2012 Aug;7 Suppl 1:S4.

2. Marttos AC, Kuchkarian FM, Rojas DF, Fraga GP, Collet-Silva FS, de Almeida Costa C, Garcia GD, Ginzburg E, Schulman CI, Namias N. Global connections: telemedicine as a tool to extend trauma education. PAJTCCES 2013 Jan;2(1):62-66.

3. Peck GL, Ferrada P, Joseph H, Ferrada R, Christopher D, Ordonez C, Aboutanos M, Gracias, V. Can we augment the US trauma fellow's operative training? The PTS fellowship: a US surgical critical care fellow's experience in Colombia. PAJTCCES 2014 Jan;3(1):1-7.

4. Ferrada P, Ivatury RR, Spain DA, Davis KA, Aboutanos M, Fildes JJ, Scalea TM. International rotations: a valuable source to supplement operative experience for acute-care surgery, trauma, and surgical critical care fellows. J Trauma Acute Care Surg 2017 Jan;82(1):51-57.

5. Knuth T. Letter to the editor. J Trauma 2013;34(6):914.

6. Ferrada P, Ferrada R, Aboutanos M, Ivatury RR. International surgical rotations: a prodigious personal and professional maturation. Am Surg 2015 May;81(5):E230-E231.

7. Ivatury R. Panamerican Trauma Society Travelling Scholarship: a cultural, clinical and surgical exchange. PAJTCCES $2014 ; 3(1)$. 
8. SimõesRL, BermudesFA, AndradeHS, Barcelos FM, RossoniBP, Miguel GP, Fagundes CA, Fraga GP. Trauma leagues: an alternative way to teach trauma surgery to medical students. Rev Col Bras Cir 2014 Jul-Aug;41(4):297-302.

9. Boeck MA, Blair KJ, Foianini E, Perry HB, Mata LV, Aboutanos MB, Haider AH, Swaroop M. Implementation of a hospital-based trauma registry in Santa Cruz de la Sierra, Bolivia: methodology, preliminary results, and lessons learned. PAJTCCES 2015;5(2):101-112.

10. Uribe A, Roriguez CS, Ordonez C, Morales M, Ivatury R, Aboutanos M. Reporte del Registro de Trauma de la Sociedad Panamericana de Trauma. Un año de experiencia en dos hospitales de la ciudad de Cali. Panam J Trauma Crit Care Emerg Surg 2015;4(3):109-123.

11. Ordonez CA, Rubiano J, Badiel M, Pino LF, Minan-Arana FD, Tejada JW, Morales M, Puyana JC, Mata L, Aboutanos M, et al. Epidemiologia Del Trauma en Dos Hospitales de Primer Nivel de Atencion Del Suroccidente de Colombia. Reporte Preliminar Del Registro Internacional deTrauma de la Sociedad Panamericana de Trauma. PAJTCCES 2014;3(1):11-15.
12. Calle-Toro JS, Ordonez C, Sanchez AI, Sanjuan J, Badiel M, Pino L, Ivatury RR, Aboutanos M. Epidemiologia de Lesiones Relacionadas con Colisiones Vehiculos Motorizados en dos Centros de Referencia del Suroccidente Colombiano. Reporte del Registro Internacional de Trauma de la Sociedad P. PAJTCCES 2014;3(1):16-22.

13. Rodriguez CS, Uribe A, Ordonez, C, Morales M, Ivatury R, Aboutnaos M. Reporte de la Tendencia del: Trauma Pediátrico en dos Hospitales de Cali en el 2012. Panam J Trauma Crit Care Emerg Surg 2015;4(3):124-135.

14. Ordoñez CA, Morales M, Rojas-MirquezJC, Bonilla-Escobar FJ, Badiel M, Miñán Arana F, González A, Pino LF, Uribe-Gómez A, Herrera MA, et al. Trauma Registry of the Pan-American Trauma Society: one year of experience in two hospitals in southwest Colombia. Colomb Med (Cali) 2016 Sep;47(3):148-154.

15. Tecker GH. Available from: https://www.asaecenter.org/ resources/.../sustaining-association-success-that-matters; [cited 2015 Nov 11].

16. President's message. www. Panamericantrauma.org. accessed Dec 31, 2016. 


\title{
Sociedad Panamericana De Trauma: Las Tres Primeras Decadas
}

\author{
${ }^{1}$ Rao R Ivatury, ${ }^{2}$ Michel Aboutanos
}

\section{RESUMEN}

La Sociedad Panamericana de Trauma nació hace 30 años con la misión de mejorar la atención de trauma en las Américas mediante la promoción e intercambio de ideas y conceptos, y la ampliación del conocimiento de trauma y enfermedades agudas. Los autores, líderes pasados inmediatos de la organización, revisan la evolución de esta asamblea de diversas culturas y nacionalidades.

Palabras claves: History, Sociedad de trauma, Sociedad panamericana de trauma.

How to cite this article: Ivatury RR, Aboutanos M. Sociedad Panamericana De Trauma: Las Tres Primeras Decadas. Panam J Trauma Crit Care Emerg Surg 2017;6(2):90-123.

Source of support: Nil

Conflict of interest: None

\section{INTRODUCCIÓN}

Hace ya treinta años que nació la Sociedad Panamericana de Trauma (SPT). Las tres décadas de su corta existencia han sido bastante memorables y dolorosas durante su crecimiento, su adolescencia, su maduración, y sus logros. Es una historia interesante de personas con varios idiomas, nacionalidades, experiencias y razas que se unen para mejorar el cuidado de pacientes quirúrgicos, críticamente heridos y enfermos en el hemisferio. Es una ruta de colaboración internacional en cirugía global para mejorar el cuidado quirúrgico en países de ingresos bajos y medios. Ahora, el alcance se ha extendido a continentes distantes.

El primer autor de esta comunicación ha tenido el privilegio de participar en esta gran odisea, primero como joven cirujano y miembro fundador, culminando en los últimos seis años en la dirección ejecutiva. Los autores acaban de terminar sus puestos oficiales como Director

\footnotetext{
${ }^{1}$ Professor Emeritus, ${ }^{2}$ Professor

${ }^{1}$ Department of Surgery, VCU Medical Center Richmond VA, USA

${ }^{2}$ Department of Surgery, Director Acute Care Surgical Services VCU Medical Center Richmond, VA, USA

Corresponding Author: Rao R Ivatury, Professor Emeritus Department of Surgery, VCU Medical Center, W 15E, 1200 East Broad Street, Richmond, VA 23298, USA, e-mail: raoivatury@ gmail.com
}

Ejecutivo y Presidente Pasado Inmediato de la Sociedad, respectivamente. El objetivo de este informe es documentar la trayectoria de la Sociedad desde su infancia hasta el estado actual de madurez. La intención no es en lo más mínimo de auto-engrandecimiento, sino para destacar la evolución de una sociedad multinacional en la era actual de mayor entusiasmo en asuntos de cirugía global. Es un homenaje para los muchos miembros individuales, Junta de Directores, Comités y Ex presidentes que colectivamente deben ser acreditados por la actual posición de la Sociedad. Esperamos sinceramente que los miembros lean esta historia, que vean con orgullo la Sociedad como propia e inspiren a otros a avanzarla más allá. Que este documento sirva también como una batuta para la nueva generación y el liderazgo entrante.

\section{EL NACIMIENTO}

La SPT fue concebida durante un almuerzo, en un restaurante de la ciudad de México llamado "Hacienda Los Morales" en 1987 durante un simposio de la Cruz Roja Mexicana. Fue un pensamiento inspirado por el Dr Armando Baqueiro de México, quien propuso crear una Sociedad con la misión de mejorar la administración de pacientes traumatizados en el Hemisferio Americano: Norte, Central y Sur; en consecuencia, con el nombre de SPT. Los visionarios fueron los Dres Baqueiro, Aurelio Rodríguez, Alejandro Grife, García Morales "El Max", Gómez Palacio, y Carlos Moreno - todos cirujanos latinoamericanos de experiencia y reputación (Figura 1). Los Dres Aurelio Rodríguez y Francisco Holguín (de Colombia) viajaron por todo el mundo latinoamericano presentando la propuesta para crear esta Sociedad. La idea fue aprobada unánimemente y la Sociedad fue fundada oficialmente en Bogotá, Colombia en 1989. Los primeros oficiales y miembros se reunieron durante el Congreso Anual de la Federación de Sociedades Quirúrgicas Latinoamericanas en Ecuador y en aquella época se designó al Dr Aurelio Rodríguez de Perú y Estados Unidos como primer presidente y Ricardo Sonneborn de Chile como el primer Vicepresidente.

\section{LA INFANCIA}

El primer Congreso Anual de la SPT se realizó en San Juan, Puerto Rico, en 1988 con la benevolencia

Esta es una versión ampliada del artículo publicado en el Journal of Trauma and Acute Care Surgery, 2017 mayo; 82(5):966973 bajo la licencia de acceso abierto de CC-BY-NC-ND 


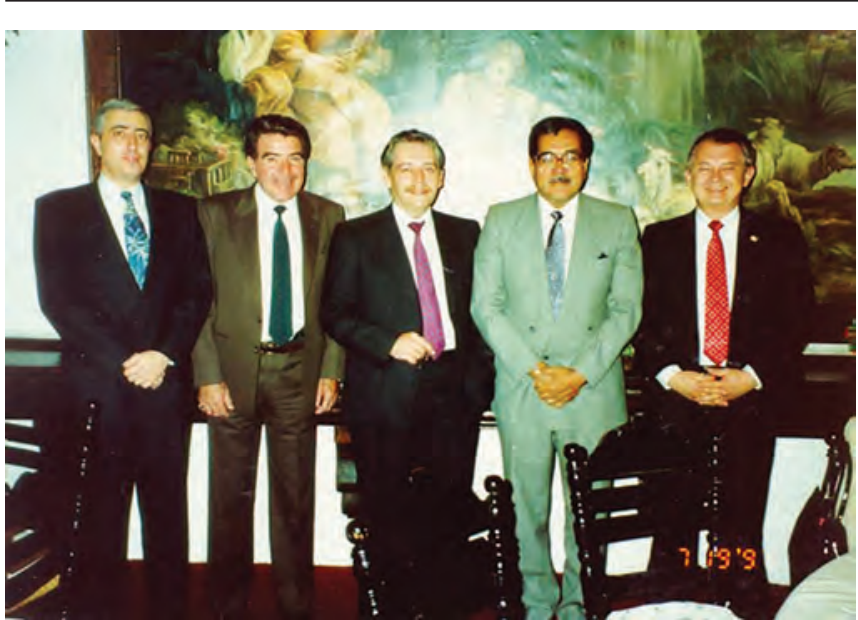

Figura 1: El "almuerzo de inspiración" donde se propuso la idea de la SPT. De izquierda a derecha: Dres: Gomes-Palacios, Carlos Moreno, Armando Baqueiro, Aurelio Rodriguez, Alejandro Grife. Falta: Garcia Morales "el max"

económica de su Gobernador. Se realizó una nueva definición de la Junta Directiva. El segundo Congreso estaba a punto de ser celebrado en 1989 en Puerto Rico. Sin embargo, hubo un intruso incómodo en forma del huracán Hugo. Consecuentemente, el Congreso nunca se celebró. Afortunadamente, tanto la Sociedad como sus visitantes sobrevivieron a esta adversidad. La segunda asamblea científica de la Sociedad se celebró el próximo año en São Paulo, Brasil. El grupo brasileño, encabezado por el distinguido profesor Dario Birolini y su grupo de Das Clínicas se unió a la SPT. La colaboración brasileña sigue siendo fuerte hasta el día de hoy. El tercer congreso en Buenos Aires, Argentina, siguió a la primera asamblea de la recién formada Asociación de Trauma de Colombia en Bogotá, Colombia. Desde entonces la SPT maduró, y un congreso se llevó a cabo anualmente cada noviembre en varios países (Recuadro 1). Los tres países principales no-estadounidenses de la SPT - Brasil, Colombia y Argentina - y sus delegados, incluyendo a los profesores Birolini, Holguín y Rasslan fueron los primeros pioneros. Un apoyo fuerte de América del Norte fue prestado por los primeros lideres - Profesores Rodríguez, Mulder, y Ernest Moore. Los profesores Feliciano, Hoyt, Maull, Mattox, Maier, Frykberg, Baker, y Briggs de los Estados Unidos; Gutiérrez y Neira de Argentina; Tovar de México y muchos otros sirvieron para desarrollar a la SPT.

Los congresos anuales de la SPT ganaron una reputación internacional con la participación de profesionales destacados de la salud en Trauma y Cuidados Críticos de todo el mundo. La Sociedad celebró su aniversario de plata (25 años) en 2015 en Medellín, Colombia, en una exhibición orgullosa de ciencia y cultura, con la mayoría de los Presidentes presentes. La participación, como se ha hecho habitual en la STP, involucró no sólo
Recuadro 1: Reuniones anuales
1987 First Board Meeting, Quito
1988 Primer Congreso de la SPT, Puerto Rico
1990 São Paulo, Brasil
1991 Buenos Aires, Argentina
1992 Guadalajara, México
1993 San José, Costa Rica
1994 Cartagena, Colombia
1995 Salvador, Brasil
1996 Cartagena, Colombia
1997 Miami, EE.UU
1998 Buenos Aires, Argentina
1999 Margarita, Venezuela
2000 Panamá, Panamá
2001 Monterrey, México
2002 São Paulo, Brazil
2003 Lima, Perú
2004 Miami, EE.UU
2005 Guayaquil, Ecuador
2006 Cartagena, Colombia
2007 Puebla, México
2008 Campinas, Brasil
2009 Caracas, Venezuela
2010 Montevideo, Uruguay
2011 Asunción, Paraguay
2012 Medellín, Colombia
2013 Santiago, Chile
2014 Panamá City, Panamá
2015 Santa Cruz, Bolivia

2016 Maceió, Brasil

a los cirujanos, sino también a los médicos de emergencia, internistas, enfermeras, paramédicos, residentes y estudiantes de medicina. La SPT acaba de terminar un exitoso Congreso en conjunto con la Sociedade Brasileira de Atendimento Integrado ao Traumatizado (SBAIT) en Maceió, Brasil en 2016.

\section{OFICIALES DE LA SPT}

A medida que la Sociedad crecía de su infancia, la diversidad multinacional y multicultural de la organización se convirtió en un pilar prominente de fuerza y un rasgo universalmente admirado. Todos los países de América del Sur y sus organizaciones existentes de trauma y cirugía comenzaron a participar y contribuir a la misión compartida de la Sociedad. Donde no existía, huboun nuevo entusiasmo para formar organizaciones locales y unirse a la SPT. Muy pronto, la Sociedad decidió alternar la Presidencia entre distinguidos cirujanos norteamericanos y sudamericanos, y la tradición sigue viva hasta el día de hoy (Anexo 1, y Figura 2).

En las últimas tres décadas, cada uno de estos líderes, , reforzó la misión común, enfatizó nuestra identidad entre la diversidad, definió metas futuras para la Sociedad e inspiró un crecimiento continuo. El Director Ejecutivo asiste a los Presidentes en sus funciones y responsabilidades. Estos dos altos oficiales de la organización y su 
Sociedad Panamericana De Trauma: Las Tres Primeras Decadas

\begin{tabular}{|c|c|c|c|c|}
\hline Año & Ciudad & Presidente & Orador de la Conferencia & $\begin{array}{l}\text { Tema: Conferencia Aurelio } \\
\text { Rodriguez }\end{array}$ \\
\hline 1988 & San Juan, Puerto Rico & A Rodríguez, (EE.UU) & & \\
\hline 1990 & São Paulo, Brasil & A Rodríguez (EE.UU) & & \\
\hline 1991 & Buenos Aires, Argentina & F Holguín (Colombia) & & \\
\hline 1992 & Guadalajara, México & E Moore, (EE.UU) & & \\
\hline 1993 & San Jose, Costa Rica & D Birolini (Brasil) & & \\
\hline 1994 & $\begin{array}{l}\text { Cartagena de Indias, } \\
\text { Colombia }\end{array}$ & C Lucas (EE.UU) & & \\
\hline 1995 & Salvador, Brasil & A Baqueiro (México) & & \\
\hline 1996 & $\begin{array}{l}\text { Cartagena de Indias, } \\
\text { Colombia }\end{array}$ & K Maull (EE.UU) & & \\
\hline 1997 & Miami, USA & R Ferrada (Colombia) & & \\
\hline 1998 & Buenos Aires, Argentina & G Gomez (EE.UU) & & \\
\hline 1999 & Isla Margarita, Venezuela & D Ortega (Perú) & & \\
\hline 2000 & Ciudad de Panamá, Panamá & D Feliciano (EE.UU) & & \\
\hline 2001 & Monterrey, México & J Neira (Argentina) & & \\
\hline 2002 & São Paulo, Brasil & R Ivatury (EE.UU) & Ricardo Ferrada (Colombia) & Education and Trauma \\
\hline 2003 & Lima, Perú & S Rasslan (Brasil) & $\begin{array}{l}\text { Gerardo Gomez (EE UU/ } \\
\text { Venezuela) }\end{array}$ & Sepsis, what is new? \\
\hline 2004 & Miami, EE.UU & S Briggs (EE.UU) & Donald Trunkey (EE.UU) & $\begin{array}{l}\text { Violencia, Drogas y Trauma en el } \\
\text { Hemisferio Occidental: Una solución } \\
\text { alternativa. }\end{array}$ \\
\hline 2005 & Guayaquil, Ecuador & J Lombardi (Chile) & Ernest Moore (EE.UU) & Blood substitutes in Trauma \\
\hline 2006 & $\begin{array}{l}\text { Cartagena de Indias, } \\
\text { Colombia }\end{array}$ & D Hoyt (EE.UU) & C. Willam Schwab (EE.UU) & The winds of war \\
\hline 2007 & Puebla, México & C Morales (Colombia) & Jorge Neira (Argentina) & $\begin{array}{l}\text { Nuevos aspectos en la resucitación } \\
\text { de volumen en la atención inicial del } \\
\text { paciente traumatizado }\end{array}$ \\
\hline 2008 & Campinas, Brasil & A Peitzman (EE.UU) & Raul Coimbra (EE UU/Brazil) & $\begin{array}{l}\text { Trauma as a Disease: The public's } \\
\text { perception }\end{array}$ \\
\hline 2009 & Caracas, Venezuela & J Garcia (Venezuela) & Renato S. Poggetti (Brazil) & Trauma prevention \\
\hline 2010 & Montevideo, Uruguay & R Coímbra (EE.UU) & Ronald Maier (EE.UU) & $\begin{array}{l}\text { Molecular and genetic aspects of } \\
\text { the response to trauma }\end{array}$ \\
\hline 2011 & Asunción, Paraguay & R Pogetti (Brasil) & Armando Baqueiro (México) & $\begin{array}{l}\text { The evolution of teaching and } \\
\text { management of Trauma in Mexico } \\
\text { in the last } 25 \text { years }\end{array}$ \\
\hline 2012 & Medellín, Colombia & J Puyana (EE.UU) & Ethan Nadelmann (EE UU) & $\begin{array}{l}\text { Why we need to end the war on } \\
\text { drugs }\end{array}$ \\
\hline 2013 & Santiago, Chile & A Pacheco (Chile) & Ricardo Sonneborm (Chile) & Origin and destination in trauma \\
\hline 2014 & Ciudad de Panamá, Panamá & M Lorenzo (EE.UU) & Stanley Motta (Panamá) & Why trauma? A personal experience \\
\hline 2015 & Santa Cruz, Bolivia & G Fraga (Brasil) & Rao Ivatury (EE.UU) & PTS: a look back and a look forward \\
\hline 2016 & Maceio, Brazil & M Aboutanos (EE.UU) & Thomas Scalea (EE.UU) & $\begin{array}{l}\text { Mentoring the future Trauma } \\
\text { Leaders: Implications for the } \\
\text { Panamerican Trauma Society }\end{array}$ \\
\hline
\end{tabular}

estrecha colaboración han sido una combinación esencial para el éxito de la Sociedad. Las personas que tuvieron el privilegio de esta posición son: los doctores Rodríguez, Holguín, Gómez, Maull, Peitzman e Ivatury. El Doctor Scalea es el nuevo director ejecutivo elegido y se ha hecho cargo desde noviembre del 2016. Con una Junta de Directores joven y ansiosa y un Secretario-Tesorero con entusiasmo y energía infatigable, la SPT hizo rápidos avances en el reclutamiento de miembros y ha mantenido el impulso. Los doctores Barba, Gómez, Peitzman, Puyana y Aboutanos merecen un crédito inmenso por sus incansables esfuerzos como secretarios-tesoreros para llevar a la Compañía al siglo XXI. El Secretario actual, Esteban Foianini, sigue ese ejemplo eminente.

\section{OFICINAS DE LA SPT}

Ubicada inicialmente en Baltimore, gracias al apoyo del Dr R Cowley en The shock Trauma Center, las oficinas se trasladaron a Connecticut con un nuevo secretario. El año 2003 trajo un cambio radical y significativo cuando el Dr Peitzman llevó la Sociedad a la Universidad de Pittsburgh y la cultivó durante los próximos 7 años. Bajo el liderazgo de los Dres Peitzman (como secretario, presidente y director ejecutivo) y Puyana (como secretario 

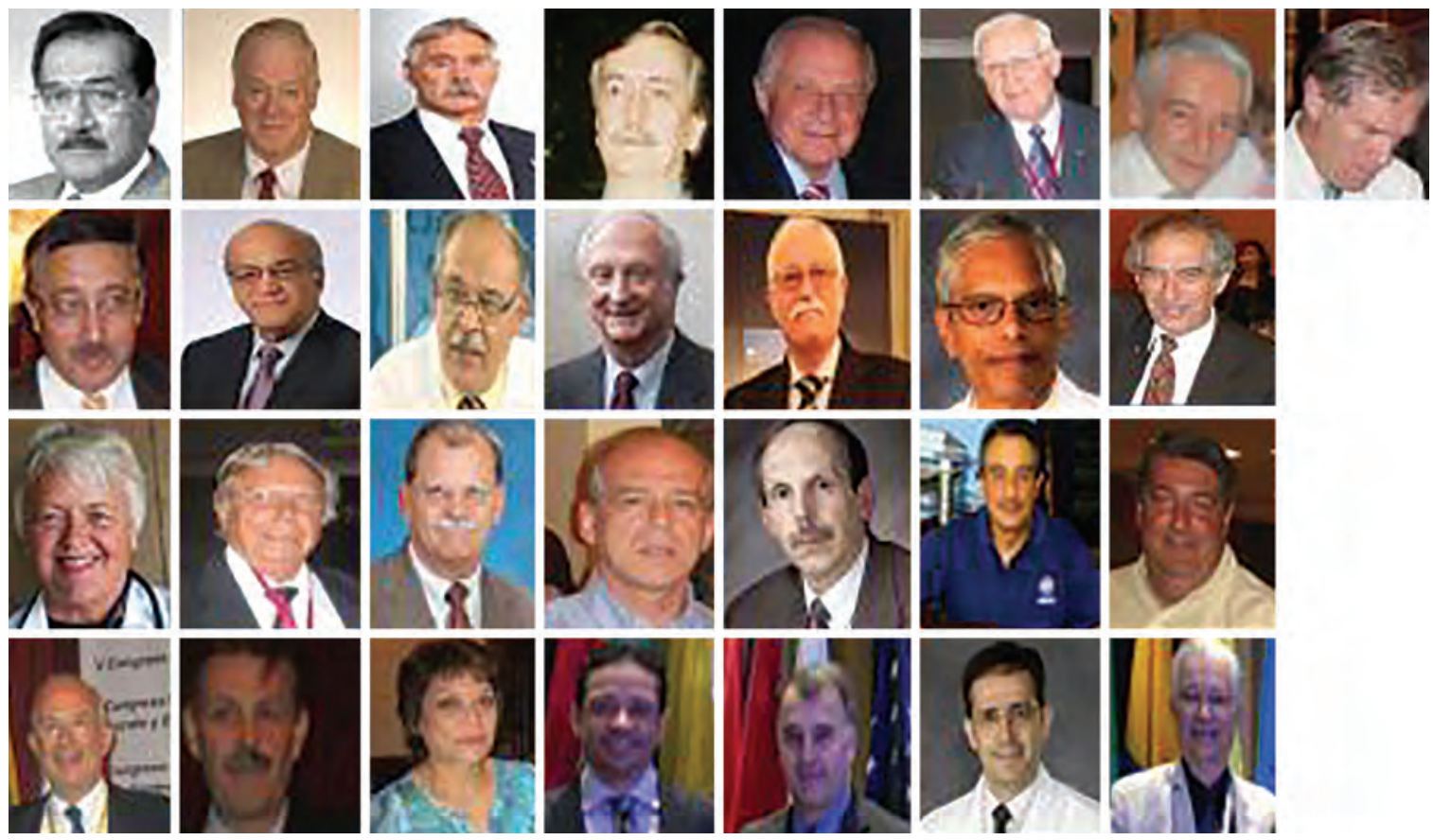

Figura 2: Presidentes de la SPT del 1987-2016

Fila 1 (Izquierda a derecha): A Rodriguez (EE.UU.), 1987-1989; D Mulder (Canadá), 1989-1990; E Moore (EE.UU.), 1990-1991; F Holguin (Colombia), 1991-1992, D Birolini (Brasil), 1992-1993; C Lucas (EE.UU.), 1993-1994; A Baqueiro (México), 1994-1995; K Maull (EE.UU.), 1995-1996

Fila 2 (Izquierda a derecha): R Ferrada (Colombia), 1996-1997; G Gomez (EE.UU.) 1997-1998, D Ortega (Perú); 1998-1999; D Feliciano (EE.UU.), 1999-2000; J Neira (Argentina), 2000-2001; R Ivatury (EE.UU.) 2001-2002; S Rasslan (Brasil), 2002-2003

Fila 3 (Izquierda a derecha): S Briggs (EE.UU.), 2003-2004; J.Lombardi (Chile) 2004-2005; D. Hoyt (EE.UU.) 2005-2006; C Morales (Colombia) 2006-2007; A Peitzman (EE.UU.) 2007-2008; J Garcia (Venezuela), 2008-2009; R Coimbra (EE.UU.), 2009-2010

Fila 4 (Izquierda a derecha): R Pogetti (Brasil) 2010-2011; J Puyana (EE.UU.) 2011-2012; A Pacheco (Chile) 2012-2013; M Lorenzo (EE.UU) 2013-2014; G Fraga (Brasil) 2014-2015; M Aboutanos (EE.UU.) 2015-2016, C Ordonez (Colombia) 2016-2017

y luego como presidente), la SPT experimentó enormes avances en reclutamiento de miembros, mantenimiento de registros, reestructuración de los cursos educativos de la SPT, y la actualización del sitio web de la sociedad.

El 12 de noviembre del 2010, la oficina sede se trasladó de Pittsburgh a la ubicación actual en Richmond, en la División de cuidados críticos quirúrgicos, Departamento de Cirugía, de Virginia Commonwealth University (VCU), con una administradora excelente, Gladys Soruco Shanklin. La SPT y VCU, bajo la benevolencia del Presidente Michael Rao y el Decano Jerry Strauss $\mathrm{MD}$, entraron en una asociación, con la universidad proporcionando una asistencia financiera significativa a la oficina de la SPT y su personal, también proporcionando crédito de Educación Médica Continuada (CME) para los congresos de la SPT. El Presidente de la Universidad, junto con el Decano y los jefes del departamento de cirugía, los doctores Neifeld y Kasirajan, asistieron a los Congresos de la SPT en el 2012 y 2015, y vincularon esta relación. En el 2016, VCU School of Medicine (la Facultad de Medicina de VCU) firmó formalmente un Memorando de Entendimiento con la SPT para el apoyo financiero continuo de más de \$ 250 mil dólares anualmente, por otros tres años.

\section{MADURACIÓN DE LA VISIÓN DE LA SPT}

Durante la última década, la SPT maduró y entró en su edad adulta. Donde antes era una organización enfocada clínicamente, ahora ha logrado un enfoque orientado en sistema de trauma. Donde una vez fue una Sociedad centrada en el Congreso, se ha convertido en una sociedad con un Congreso. Antes era una sociedad nómada con migraciones frecuentes, ahora es una sociedad con oficina central en una universidad. En este proceso de maduración, se ha establecido un camino para lograr la independencia financiera y convertirse en una organización solvente. La siguiente narración intentará ilustrar parte de este progreso.

\section{Servicios de Afiliación}

A partir del 2015, la membresía de la Sociedad ha alcanzado a 27 países (21 países de América Latina y el Caribe Argentina, Bolivia, Brasil, Canadá, Chile, Colombia, Costa 
Rica, Cuba, Curazao, Ecuador, El Salvador, Guatemala, México, Nicaragua, Panamá, Paraguay, Perú, Estados Unidos, Uruguay, Venezuela) (y 6 otros países - Angola, Finlandia, Qatar, Países Bajos, Noruega y España). A iniciativa del presidente del comité la Dra Maria F Jiménez, se están realizando esfuerzos activos para aumentar la membresía de la SPT.

\section{Sitio web de la SPT}

La SPT ha visto avances significativos en el desarrollo de su sitio web bajo el liderazgo de los Dres. Peitzman y Puyana (2003-2010). Con el traslado de la sede de la SPT a Richmond, Virginia en 2010, se tomó una decisión crucial para establecer el sitio web de la SPT independiente del servidor de la Universidad y sus paredes de seguridad (firewalls) obligatorios. Esto permitió un avance exponencial en la funcionalidad del sitio web para servir a los miembros de la SPT. Proporcionó un sistema automatizado de conmutación entre tres idiomas (inglés, español, y portugués), un sistema de comunicación automatizado (2011), un sistema de pago en línea automatizado (2012), y un sistema de envío y evaluación de resúmenes para concursos de investigación automatizado (2013). Con la ayuda del ex vicepresidente Daniel Ludi, se desarrolló en Vimeo una plataforma de alojamiento y distribución de vídeos (2014). Esta última característica hace posible la disponibilidad de una miríada de conferencias de destacados expertos en trauma y atención de emergencia. Las mejoras recientes fueron: Educación médica continua en línea, despliegue del sitio web en dispositivo móvil, centro de noticias y enlaces de sitio web a medios sociales (2015-16).

\section{La agenda Educativa de la SPT}

La misión compartida de los miembros de la SPT es mejorar el cuidado de los enfermos o de los críticamente lesionados en las Américas, especialmente en América del Sur. La Sociedad pretende lograr esto con énfasis constante en la colaboración y educación médica continua, con un comité de educación energizado bajo la dirección de la Dra Paula Ferrada.

La SPT cree que las mejoras en el cuidado del paciente lesionado o enfermo, incluso en aquellos países con recursos limitados, son viables y dependen de organización y planificación. Sostiene que la educación y el aprendizaje basado en práctica a través de todos sus cursos tendrán un impacto positivo en la gestión del paciente. A partir del 2010-2015 se realizaron 136 cursos, muchos de ellos a través del SBAIT. Algunos de los cursos que fueron realizados son: Destrezas Quirúrgicas en Trauma (DQT), Ultrasonido en Emergencias y Trauma (USET) básico y avanzado, Respuesta Médica Avanzada a Desastres (ADMR), Curso de Mejoramiento de Calidad de la Organización Mundial de la Salud (OMS), Curso Esencial de Trauma para médicos / enfermeras/personal pre hospitalario, Manejo de Quemaduras, Enfermería en Trauma, Curso de Rescate Médico Aéreo, y un curso Pre Hospitalario, entre otros. Estos cursos están estandarizados y se propagan mediante el uso de tecnología (basado en la web) y también por las redes sociales. La demanda de estos cursos está aumentando en toda América Latina, ya que están diseñados especialmente para los profesionales y proveedores de atención médica en países de recursos bajos y medianos, y son más asequibles que los cursos europeos o americanos.

\section{La Conferencia Aurelio Rodríguez}

Iniciada en el 2002 y dada en el congreso anual por invitación del Presidente, fue creado para honrar al fundador, visionario y líder de la SPT. Es un homenaje por su presencia, contribuciones y participación que proporcionan el "pegamento" para mantener la sociedad unida. El discurso, sobre un tema contemporáneo, pronto se convirtió en un punto culminante del congreso y es muy valorado por el conferencista y la audiencia. Estos se enumeran en el Anexo 1.

\section{Participación de las sociedades locales}

La siguiente iniciativa de la SPT es involucrar a las sociedades locales y ayudarles a organizar actividades educativas, ofreciéndoles cursos de la SPT a precios reducidos y proporcionando ayuda con profesores y materiales. La SPT también actúa como la organización madre de varias organizaciones de traumatología en México, Ecuador, Colombia, Panamá, Bolivia, Perú, Paraguay, Uruguay, Brasil y Argentina.

\section{Exposición de investigaciones y publicaciones de América del Sur}

Es bien conocido que el cuidado de las lesiones y enfermedades quirúrgicas es abrumadoramente complejo en su incidencia y severidad en estos países, aun cuando los sudamericanos son reconocidos por su inmensa rica experiencia en estos campos. Además de las habilidades quirúrgicas que esta experiencia les trae, han desarrollado muchas soluciones innovadoras y de bajo costo en su práctica clínica adecuada a sus propias condiciones económicas. Entre los principales ejemplos se encuentran la bolsa de Borraez (Bogotá) para el cierre temporal del abdomen de Colombia, el paquete de Pogetti (para la compresión interna de los tractos de misiles del hígado) de Brasil y la primera reparación de aneurisma de la aorta abdominal endovascular (Parodi, Buenos Aires). Muchos de estos acontecimientos emocionantes tienen lugar todos los días en América del Sur y la SPT ofrece a 


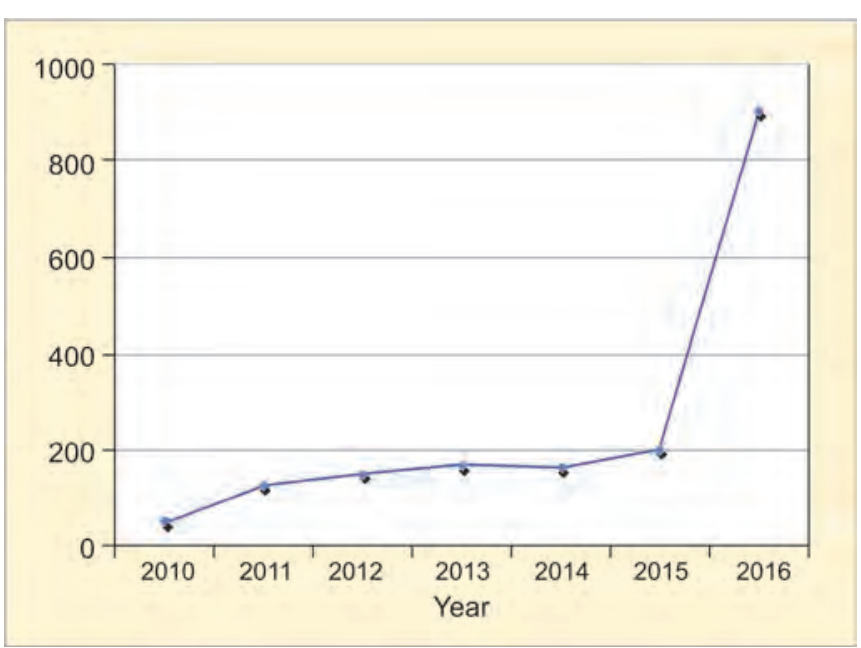

Grafico 1: Número de resúmenes enviados para participar en el congreso anual (2010-2016)

estos innovadores una vía para mostrar sus talentos en los congresos y en publicaciones (La Revista Oficial de la Sociedad, libros de texto, etc...)

\section{Concursos SPT de Investigación}

Los concursos, celebrados anualmente en el Congreso de la SPT, para médicos, residentes y estudiantes, han experimentado un enorme crecimiento en el número de resúmenes presentados al Congreso durante los últimos 5 años (Grafico 1). Hubo un récord de 900 resúmenes en 2016, lo que llevó a 80 presentaciones orales y 313 presentaciones mini-orales en el congreso. Se dedicó una sesión entera a prevención de lesiones.

De hecho, el número de manuscritos enviados a la revista de la sociedad, The Panamerican Journal of Trauma, Critical Care and Emergency Surgery - PAJTCCES (la Revista Panamericana de Trauma, Cuidados Críticos y Cirugía de Emergencia) ha aumentado con una constante notable mejoría en la calidad.

Las becas de viaje para los resúmenes ganadores son donaciones proporcionadas por la ex presidente Dra Susan Briggs, para resúmenes de manejo de desastres, y para resúmenes de prevención de lesiones el ex presidente Dr Michel Aboutanos y el Dr Terrence O'Keefe (: brillantes ejemplos de inspiración. Impresionantemente, el actual Presidente Carlos Ordóñez y su equipo de Cali se han destacado por haber logrado colocar sus resúmenes en las presentaciones orales sumamente competitivas de la reunión anual científica del AAST. Su récord reciente de múltiples publicaciones en revistas internacionales ha establecido nuevos estándares para la SPT.

\section{Publicaciones de la SPT}

La SPT está activamente publicando libros, manuales y guías escritos por sus miembros. Muchos de ellos han sido transferidos como propiedad de la SPT. Los ejemplos incluyen: TRAUMA, (el manual oficial de la SPT actualmente en fase de revisión para una nueva edición que estará disponible en ambos formatos impresión y e-book (libro electrónico) que se espera en el 2017); Guidelines for Trauma Quality Improvement Programs (Lineamientos para Mejorar la Calidad de Programas de Trauma) (junto con la OMS) en inglés y portugués; Manuales de USET Avanzado en español; USET y ADRM en portugués y español; Quemaduras en español. Otras publicaciones hechas por miembros de la SPT fueron traducidos al español por ejemplo: Abdominal Compartment Syndrome; Trauma Manual; US in the ICU; Cuidado Intensivo y Trauma; y Guías de Desarrollo de Sistemas de Trauma y Cuidados Esenciales de Trauma para América Latina.

\section{LA Revista}

La SPT ha mantenido durante mucho tiempo su propia revista, la Revista Panamericana de Trauma, bajo la dirección del Dr Ricardo Ferrada. Después de una interrupción, la publicación de la revista se reanudó en el 2012 con un nuevo consejo editorial, bajo la dirección editorial del Dr Rao Ivatury y Jaypee Publishers de la India. Publicada trimestralmente como una publicación electrónica, abarca todos los aspectos de trauma, cuidados críticos y cirugía de emergencia. Aspira ser un vehículo para todos los miembros de la SPT, para que ellos muestren su vasta experiencia clínica, y al parecer está teniendo éxito en esta misión. Más importante aún, se ha convertido en un recurso para la generación más joven de estudiantes de medicina, residentes, y cirujanos profesores jóvenes en sus esfuerzos por iniciar reportes científicos. También se ha convertido en un conducto para la publicación de artículos presentados en concursos de investigación en el congreso anual. El Consejo Editorial se compromete a seguir atrayendo la investigación clínica basada en el abundante material que es proporcionado a los miembros de la SPT, y también promete alentar a los jóvenes cirujanos e internos a publicar. La indexación de Medline por la Biblioteca Nacional de Medicina es un objetivo vital que esperamos pueda ser alcanzado este año.

\section{Las rondas internacionales de trauma}

El Dr Antonio Marttos y University of Miami/ Ryder Trauma Center (Universidad de Miami/Centro Ryder de Trauma) establecieron las Rondas Internacionales de Trauma, que abarcan semanalmente presentaciones de casos televisados y presentados por los cirujanos de trauma de todo el mundo. A través de video conferencias, semanalmente se discuten presentaciones de casos complejos de trauma y temas avanzados de cuidados críticos. Las presentaciones de casos ofrecen a los estudiantes, residentes, 
becarios y médicos una excelente herramienta para la educación y el intercambio de conocimientos médicos a través de las fronteras. Los médicos elegibles pueden obtener créditos de educación médica continua (CME). Hasta la fecha, se han registrado 42 instituciones participantes, entre ellos: Estados Unidos, Brasil, Colombia, Bahamas, Haití, Canadá, Venezuela, Argentina, Panamá, Puerto Rico, República Dominicana, Islas Vírgenes Británicas, España, Tailandia, Turquía e Irak; Desde centros médicos académicos hasta centros de traumatología urbana, hospitales militares, comunitarios y rurales. ${ }^{1,2}$ La SPT ha adoptado estas Tele-Rondas como una de sus actividades educativas. En un acuerdo académico, estas conferencias se anuncian en el sitio web de AAST para su información y participación. Se están realizando esfuerzos para convertir algunas de estas conferencias en publicaciones completas en la Revista de Cirugía de Trauma y Cuidados Críticos.

\section{Fellowships y Becas Internacionales}

La SPT se involucró en la facilitación de oportunidades de entrenamiento para residentes jóvenes así como para cirujanos jóvenes, para que ellos hagan uso del enorme material clínico disponible en América del Sur y America Central, de la ciencia y el arte de los sistemas de trauma en los EE.UU., ${ }^{3,4}$ El objetivo de la beca es mejorar la capacitación quirúrgica de los "fellows" becarios y brindar oportunidades a la institución anfitriona para que experimente la investigación y el intercambio.

Los eruditos norteamericanos se benefician al coordinar su visita con un centro de excelencia en Sur o Centro de América, con un anfitrión local experto que organiza la visita, la SPT ofrece opciones de vivienda, detalles logisticos necesarios de viaje Algunos ganadores recientes de estas becas internacionales incluyen residentes de East Carolina University (la Universidad de Carolina del Este), University of Miami (la Universidad de Miami), Emory University (la Universidad de Emory) e Indiana University (la Universidad de Indiana). Otros ejemplos incluyen un becario viajero a Bolivia para trabajar en el Registro de Trauma de la SPT (descrito abajo), o un viajero para entrenamiento en Ultrasonido en Cuba. Estas oportunidades de Becas Internacionales se cubrieron con donaciones generosas de miembros individuales (como la Dra Paula Ferrada), y Post-Graduate Fellowship in Global Health at Northwestern University Feinberg - SOM's Center for Global Health (Beca de Postgrado en Salud Global de la Universidad Northwestern de Feinberg,Centro de Salud Global de la SOM), bajo la dirección de la Dra Mamta Swaroop.

A cambio, las instituciones anfitrionas de la región latina desarrollan relaciones con instituciones norteamericanas, proporcionando oportunidades para establecer contactos y fomentar la investigación y programas de colaboración. Las instituciones norteamericanas proveen el Programa de Observación Internacional de la SPT, descrito a continuación, así como las becas internacionales de investigación. Estas becas tienen como objetivo proporcionar a los aspirantes cirujanos-científicos de trauma de la región latina, la oportunidad de capacitación en investigación de servicios de salud y desarrollo profesional en instituciones norteamericanas. Algunos ejemplos son: un becario viajero a Bolivia, otro viajero para capacitarse en ultrasonido en Cuba, y un becario de investigación en The Center for Surgery and Public Health (CSPH) at Brigham and Women's Hospital (el Centro de Cirugía y Salud Pública (CSPH) en el Hospital de Brigham y mujeres), bajo la tutoría del Dr Adil Haider, con un enfoque en resultados funcionales y recuperación tras emergencias de trauma.

Rotaciones de corto plazo (de 3 a 6 semanas) también están disponibles para médicos, enfermeras, paramédicos y estudiantes de América del Sur para visitar a los centros de trauma en EE.UU., para observar, auditar, experimentar el desarrollo y operaciones del sistema de trauma, las distintas actividades de mejora de calidad y desarrollo del equipo de trabajo y administración para el cuidado de los pacientes quirúrgicos, lesionados, o críticamente enfermos. Este Programa de Observación Internacional está disponible a miembros extranjeros calificados que deseen visitar y observar ciertas actividades clínicas y educativas de centros de trauma afiliados. Sólo en VCU, un total de 19 observadores (de médicos generales hasta "fellows" de trauma) aprovecharon esta oportunidad, visitando desde países como Colombia, Brasil, México, Chile, Ecuador y Sudán.

Otros centros como University of Pittsburgh Medical Center (el Centro Médico de la Universidad de Pittsburgh) y Alleghany Medical Center (Centro Médico Alleghany) del estado de Pennsylvania, Riverside County Regional Medical Center (el Centro Médico Regional del Condado de Riverside), University of San Diego (la Universidad de San Diego) University of Southern California (la Universidad del Sur de California) del estado de California, y también Indiana University (la Universidad de Indiana) participan activamente. La SPT y sus 18 sociedades afiliadas y universidades, como la Universidad del Valle en Cali, Colombia, ofrecen ejemplos notables. Desde el 2011, sus "fellows" de Trauma y Cirugía de Cuidados Críticos han tenido la oportunidad de hacer una pasantía de tres meses en Virginia Commonwealth University (VCU) y también en University of Pittsburgh.

En el pasado, muchos becarios del R Adams Cowley Shock Trauma Center (Centro de Trauma de Choque de R Adams Cowley) de Baltimore, Maryland de los EE.UU, así como becarios de Israel y otras partes del mundo, pasaron un mes bajo la tutela del Dr Ricardo Ferrada en Cali, Colombia, y tuvieron una enorme experiencia de 
casos desafiantes de trauma. Testimonios brillantes de esta experiencia fueron reportados por Knuth, Ferrada y otros..$^{5-7}$

\section{Programa de Intercambio de Paramédicos:}

El énfasis en el cuidado, entrenamiento y desarrollo pre hospitalario en la región latinoamericana se convirtió en una importante misión de la sociedad, por lo que creamos un subcomité dedicado al cuidado pre hospitalario, cursos pre hospitalarios, sesiones pre hospitalarias en el congreso anual, y el Programa de Intercambio Paramédico. En el 2014, The Virginia Association of Volunteer Rescue Squads - VAVRS (la Asociación de Escuelas de Rescate Voluntarias de Virginia) y la SPT, bajo el liderazgo de Jane Laverne (EE.UU.) y el Dr Andrés Rubiano, Presidente del Comité Pre hospitalario de la SPT, desarrollaron un Programa de Intercambio Pre hospitalario entre personal pre hospitalario del estado de Virginia y el personal pre hospitalario de varias ciudades de Colombia. El resultado fue un intercambio recíproco de paramédicos quienes compartieron invaluable conocimiento y experiencia de primera mano, y un entrenamiento discreto en respuesta a emergencias en países de altos y bajos niveles de recursos. Estos intercambios fueron mejorados con rotaciones a corto plazo con Richmond Ambulance Authority (Autoridad de Ambulancias de Richmond), y la Oficina Estatal de Servicios Médicos de Emergencia de Virgina.

\section{Educación de Enfermería}

Desde el principio, la SPT ha dado un respeto enorme al componente de enfermería, reconociendo este campo como una parte importante del equipo. Los pioneros de la sección de enfermería de la SPT, como Mary Beachley del Instituto de Ciencias Médicas de Maryland y Vivian Lane de Connecticut, realizaron actividades educativas exitosas para enfermeras durante los congresos de la SPT. Cristiane de Alencar Domingues de São Paulo, Brasil, también lidera el componente de enfermería de la SPT con energía y entusiasmo.

La SPT, junto con Rutgers Robert Wood Johnson Medical School (la Escuela de Medicina Rutgers Robert Wood Johnson), Rutgers School of Nursing (la Escuela de Enfermería Rutgers) y Robert Wood Johnson University Hospital-RWJUH (el Hospital Universitario Robert Wood Johnson - RWJUH, patrocinados por una subvención de Rutgers Centers for Global Advancement and International Affairs (los Centros Rutgers para el Avance Global y Asuntos Internacionales), organizaron un simposio mundial de enfermería en New Jersey, EE.UU. en junio del 2016 bajo la dirección del Dr Peck. Consuelo Burbano, de la Universidad de Valle de Cali, Lisa Falcon, y Sue Willard de Rutgers University, proveyeron un amplio panorama de conceptos de sistemas de trauma y la aplicación en países de bajo y medianos recursos, enfocándose específicamente en el desarrollo de un enfermero(a) de trauma en un papel de administrador. La SPT organizó cursos de enfermería de trauma para seis participantes de enfermería de Kenia y Colombia durante el simposio. Este esfuerzo estuvo a cargo de Cristiane de Alencar Domingues, Gaspar Reboredo, y Jasmine Garces. Este es un ejemplo excelente de alianzas académicas entre universidades estadounidenses de alto ingreso que comparten con misiones comunes de atención quirúrgica en América Latina. El simposio del 2017 fue celebrado a finales del mes de marzo.

\section{Ligas do Trauma}

Las ligas académicas han surgido en Brasil como una experiencia docente en la década del 1990, que consta de asociaciones de estudiantes bajo la tutoría de un profesor supervisor. La Liga de Trauma de la UNICAMP (Universidad de Campinas) fue iniciada por el Dr Mario Mantovani en Campinas, Brasil y nutrido por uno de los ex presidentes de la STP, Gustavo Fraga., En 1999 la UNICAMP y otras 9 Ligas de Trauma formaron el Congreso Brasileño de las Ligas de Trauma CoBRaLT. Las Ligas de Trauma más grande.. Ellos se enfocan en los conceptos de trauma y el cuidado de emergencia. Exponen a los estudiantes a las áreas de emergencia, salas de operación, y áreas de cuidado pre-hospitalario. También estimulan el interés por el Trauma como carrera ${ }^{8}$. CoBRaLT es el comité central de todas las Ligas de Trauma en Brasil, representándolas y coordinándolas en todos los aspectos de trauma y Cirugía de Emergencia. Organiza el congreso anual del Congreso Brasileño de Ligas de Trauma, reuniendo a más de 800 estudiantes de medicina de diferentes escuelas. Ligas similares se han iniciado en EE.UU., en las ciudades de Pittsburgh y Richmond.

En el 2013, se creó la primera Liga Ecuatoriana de Trauma y Emergencia (LATE) con el apoyo de 2 universidades; Universidad del Azuay y Universidad de Cuenca, en la ciudad de Cuenca, Ecuador. Esto coincidió con la inauguración de un nuevo Servicio Médico de Emergencia (SIS ECU 911) y el desarrollo de nuevas tecnologías del Centro de Traumatología y Emergencias del Hospital Vicente Corral Moscoso (HVCM). En el 2013, LATE tuvo 40 estudiantes y 4 tutores, trabajando en cuatro áreas principales: prevención y promoción en el campo del trauma, educación médica, investigación, y un comité de control y disciplina., La emoción de LATE se evidenció por el número de estudiantes que querían pertenecer (113 en 2013 y 400 en 2014). ¡Sólo 45 y 42 respectivamente, fueron admitidos! La composición actual asciende a 80, que fueron responsables por 
28 proyectos exitosos, incluyendo: un taller de sutura y bloqueo anestésico, primeros auxilios en trauma, curso básico de trauma de la SPT, "Respeto a la llamada 911" para evitar llamadas falsas, "Conviértase en un donante de sangre", y educando a los estudiantes de la escuela secundaria sobre el papel del primer respondedor (612 estudiantes). Otros logros fueron: acercamiento a casi 5,000 personas, cinco publicaciones, 16 cursos de capacitación, 14 campañas de promoción, 10 presentaciones orales, tres Becas Internacionales de Viaje de la SPT en 2014, 2015, 2016; primer lugar en la presentación oral en el Congreso de la SPT en el 2013 en Panamá, y 20 proyectos de investigación (17 terminados).

Colombia es el país más reciente donde se ve el aumento de ligas de trauma, una de la cual es: Liga de Trauma y Emergencias del Pacífico. Esta liga está ubicado en Cali bajo la dirección de la Fundación Valle de Lili y actual Presidente de la SPT, Dr Carlos Ordóñez. Tiene más de 50 estudiantes de medicina, todos miembros de la SPT.

El cuerpo estudiantil de las Ligas de Trauma está creciendo no sólo en números, sino también en participación en congresos locales e internacionales con calidad mejorada de participación académica. Es cierto que las Ligas de Trauma no fueron una iniciativa original de la SPT. Sin embargo, muchas de las ligas y organizaciones estudiantiles internacionales son miembros de la SPT y ahora aprovechan el congreso anual de la SPT para realizar su encuentro internacional y para una interconexión profesional.

La SPT tiene su propia sección de estudiantes con una estructura administrativa que involucra la membresía de varios países. Ha sido muy activa en los últimos congresos de la sociedad, llevando a cabo su propio programa científico con la ayuda y participación de altos miembros de la Sociedad.

La SPT está orgullosamente involucrada llevando adelante el gran movimiento de la juventud y creando oportunidades robustas para su escalada.

\section{EL REGISTRO}

Cambiar la trayectoria de la víctima colosal del trauma requiere estrategias preventivas informadas a través de vigilancia de lesiones e identificación de factores de riesgo. La magnitud de la falta de datos confiables deja el problema de lesiones ampliamente desconocido en muchos países de recursos limitados. Los registros de trauma prometen llenar este vacío mediante la captura de información sobre la continuidad de atención de pacientes, así como una herramienta para supervisar la calidad de atención. A pesar del amplio reconocimiento del valor de los registros de trauma y su extensa adopción en los países desarrollados, sólo se documentan en la bibliografía 50 registros de 21 países de recursos limitados. ${ }^{9}$ Esta enorme carga de lesiones en países de recursos limitados necesita ser definida en su naturaleza y magnitud. Esto justifica las palabras de Margaret Chan, Directora General de la OMS: "La verdadera necesidad (en salud global) es cerrar las brechas de datos, especialmente en los países de ingresos bajos y medianos, para que ya no tengamos que depender en gran medida de modelización estadística para datos sobre la carga de enfermedad". ${ }^{10}$

La SPT, con la ayuda del Programa Internacional de Desarrollo de Sistemas de Trauma (ITSDP) Virginia Commonwealth University (VCU) ha sido un pionero en este campo, habiendo desarrollado un Registro de Trauma para este propósito. La implementación inicial en países como Ecuador, Colombia y Panamá ha llevado a la recolección de datos importantes y muchos reportes analíticos de estos países. Entre los ejemplos se incluyen 15 publicaciones (9 de ellas publicadas en la revista de la Sociedad) sobre el registro, con datos del registro de la SPT recogidos en el Hospital Universitario del Valle y en la Fundación Valle del Lili (El centro de traumatología nivel I más grande de la región suroeste de Colombia). ${ }^{11-14}$

Los recientes avances a las versiones iniciales del registro han sido impresionantes: la nueva versión está disponible para computadoras de escritorio y portátiles, tiene diseño móvil, es escalable, y compatible con dispositivos múltiples como Smartphone, iPads y otras tabletas. El sistema modular y el diseño de la base de datos permiten una rápida personalización. El agrupamiento lógico de elementos permite activar y desactivar elementos en nivel de categoría. El nivel pre hospitalario captura un total de 22 puntos de datos, y el nivel de los elementos esenciales captura 27 elementos de datos correspondientes al número mínimo de puntos de datos necesarios para apoyar un programa de calidad de trauma. El Nivel 2 incluye elementos adicionales y la codificación ICD10. Un registro completo tiene 250 elementos de datos para la captura integral de datos de lesiones en varios niveles de los establecimientos de salud (básicos, hospitales generales, centros de referencia definitiva). El ITSDP se encarga tanto de la fase inicial, como la ejecución del registro en los países interesados. Esperamos progresar hasta el punto de convertirnos en un banco panamericano de datos de trauma.

\section{COLABORACIÓN INTERNACIONAL}

La SPT ha buscado continuamente la colaboración con organizaciones y sociedades internacionales de traumatología. En los últimos 5 años, se estableció una colaboración con the Trauma Association of Canada (la Asociación de Trauma de Canadá), the Eastern 
Association for the Surgery of Trauma (la Asociación Oriental para la Cirugía de Trauma), the World Society of Emergency Surgery (la Sociedad Mundial de Cirugía de Emergencia), and the Trauma Center Association of America (la Asociación de Centros de Trauma de América). En el 2012, la SPT co-organizó el Congreso Mundial de Trauma en Río de Janeiro, con 3,500 asistentes; ese mismo año, se convirtió en miembro de la Coalición Mundial de Trauma y participó en los dos congresos mundiales,- Frankfurt en el 2014, y Nueva Delhi en el 2016. En el 2013, la SPT se convirtió en un miembro oficial de la Organización Mundial de la Salud para la Alianza Mundial para el Cuidado de lesionados.Lo más notable en el 2016 fue la resolucion de un Memorandum de entendimiento con American Association for the Surgery of Trauma (AAST) (la Asociación Americana de Cirugía de Trauma) en las áreas de intercambio internacional de fellows e investigadores, y Tele-rondas internacionales de trauma.

Aparte de las sociedades individuales, se firmaron múltiples memorandos de entendimiento con centros académicos individuales que fomentan la misión de la Sociedad. Estos incluyen memorandos de entendimiento con University of Miami (Universidad de Miami) para Tele-rondas internacionales, University of Seattle (Universidad de Seattle) para desarrollar una plataforma QI (mejoría de calidad) en línea, VCU para desarrollar el registro de la SPT, y la Universidad de Azuay y la Red Nacional de Investigación y Educación del Ecuador para el desarrollo de una plataforma electrónica de EsTC (Pautas esenciales para el cuidado del trauma) para la evaluación y verificación de centros de trauma en la Región Latina - pasos prudentes en el desarrollo de herramientas para el desarrollo de sistemas de trauma en la Región Latina. La plataforma EsTC fue puesto a prueba en el 2015 en Bolivia para una evaluación de dos hospitales urbanos grandes para la verificación de sus recursos y capacidades para cuidar a los lesionados. El impacto y el desarrollo de estas herramientas básicas pueden ser aplicables en otros países de recursos bajos y medianos con ajustes menores. Recientemente se firmó un memorando de entendimiento con el Instituto Médico Sri Venkateswara de Tirupathi (SVIMS) en Andhra Pradesh, en el sur de la India, para implementar el cuidado y la educación de trauma en ese estado.

\section{PREVENCIÓN DE LESIONES Y VIOLENCIA}

La prevención de lesiones se convirtió en un componente integral de la misión de la sociedad, ya que es esencial para la nueva dirección de la STP para abordar los sistemas de atención de trauma. Las conferencias esporádicas iniciales en los congresos de la SPT antes del 2010 han evolucionado en la organización de un comité de prevención de lesiones y violencia de la SPT en el 2012, y un programa internacional de becas de viaje de prevención de lesiones y violencia en el 2013. En particular, en el 2006 se lanzó un concurso de investigación dedicado a la prevención de lesiones, destacando 20 presentaciones en podio de los siguientes países: Estados Unidos, Brasil, Argentina, Venezuela, Ecuador y Colombia. En el 2014, el ex presidente Gustavo Fraga inspiró a la SPT para unirse al movimiento internacional Yellow May (Mayo Amarillo), iniciado en Brasil, para promover la conciencia global de las lesiones por accidentes de tránsito y la importancia de su prevención. Adicionalmente, en el 2015, se estableció un memorando de entendimiento con National Network of Hospital Based Violence Intervention Programs -NNHVIP (la Red Nacional de Programas de Intervención de Violencia Basados en Hospitales) de los Estados Unidos para promover iniciativas internacionales y el desarrollo de programas colaborativos. Por último, en el discurso presidencial del Dr M Aboutanos en el 2016, el pidió a la SPT que desarrollara herramientas para la prevención de lesiones y violencia basadas en la comunidad hospitalaria que incluyen: 1. Lineamientos esenciales para el desarrollo de programas de prevención de lesiones, 2 . Base de datos regional de prevención de lesiones integrada con el registro de la SPT, 3. Guías hospitalarias para intervención, investigación y subvenciones, y 4. una plataforma integrada para evaluaciones de los sitios.

\section{EN RESUMEN}

La SPT ha entrado en su cuarta década con muchos logros, habiendo sobrevivido a desafíos considerables. Esto ejemplifica la anatomía de una sociedad exitosa, creada por una razón unificada: hacer cosas de valor e importancia que pueden hacerse mejor juntos. El liderazgo de la SPT aprecia esta característica distintiva. La SPT está liderada por políticas y estrategia, no por la personalidad de un momento dado. ${ }^{15}$ Expone una coherencia en la búsqueda de lo que realmente importa, su misión declarada. Los Presidentes de la sociedad han sido consistentes en dar a sus miembros un mensaje de unidad entre la diversidad "vea el valor de los miembros, la importancia de asistir a nuestra reunión anual y la oportunidad de involucrarse en los negocios de la sociedad" (R Coimbra, 2010); "Necesitamos: ampliar la participación oficial de las Juntas de la Sociedad de Traumatología de los distintos países de la SPT.... Organizar sociedades de trauma en países americanos que no la tienen y promulgar cursos de traumatología existentes,.... Integrar acciones e intercambiar experiencias entre la SPT y las sociedades regionales sin perder nuestra identidad "(R Poggetti, 2011); “El 
futuro de la SPT es prometedor.... El programa científico es de alta calidad" (JC Puyana, 2012); “...La Sociedad se ha convertido en una fuerza relevante en el desarrollo de cursos educativos, programas de prevención, publicaciones y foros de investigación científica que mejoran la gestión de trauma...... "(M Lorenzo, 2014). Por último, M Aboutanos, Presidente Pasado inmediato de la SPT, definió para nosotros la próxima frontera: "Igualmente, no podemos hablar de sistemas si nuestra sociedad no está involucrada en crear y avanzar las mismas herramientas que crean el sistema, incluyendo los registros de datos y su gestión, así como las iniciativas de mejora de la calidad pre hospitalaria y hospitalaria...." ${ }^{\prime 16}$.

La SPT ha recorrido un largo camino junto con sus sociedades familiares: un crisol de diferentes razas, culturas y nacionalidades con un sueño y una misión compartida. Sin lugar a dudas, ha mejorado la atención al paciente mediante el intercambio de ideas y conocimientos especializados, ampliando el alcance de la práctica más allá de las lesiones a la enfermedad crítica. A través de cursos educativos, becas y observaciones internacionales, estimuló a jóvenes. Estimuló el interés en nuestra especialidad y encendió llamas de curiosidad y liderazgo en ellos. Presentó la vasta experiencia traumática de Sudamérica y la innata habilidad quirúrgica de los cirujanos latinoamericanos. Creó nuevos paradigmas aplicables a estos países. Inició estrategias de prevención de lesiones y está a punto de abordar los problemas de sistemas.

Es crucial que la SPT mire hacia el futuro y enfrente a los desafíos que inevitablemente acechan a la vuelta de la esquina. La incertidumbre, el cambio y el riesgo son un hecho. El tratamiento de la complejidad implica receptividad activa, claridad, apertura y consenso. ¿Dónde debería estar la SPT en más o menos una década? ¿Qué trabajo hay que hacer y quién debe hacer qué? ¿Está funcionando lo que estamos haciendo actualmente? Hay preguntas pragmáticas que el nuevo liderazgo y la Sociedad deben enfrentar y responder estratégicamente: ¿Qué es la SPT? ¿Es una colección de diferentes sociedades locales, o es una familia integrada donde las sociedades están dispuestas a perder su identidad por el bien mayor, o mayor premio? ¿Es verdaderamente "panamericana"? ¿Hay una necesidad de "cortar el cordón", como algunos han sugerido? ¡Es muy presuntuoso y presumido pensar que una parte de nuestra sociedad es el "cordón" de alimento para el otro!

Para concluir, declaramos humildemente que es imperativo que la SPT comprenda que en este sistema cada vez más complejo, el orden fluye de las interacciones, no del control central. Debería seguir haciendo hincapié en las pequeñas acciones positivas de sus miembros para beneficiarse de estas interacciones y adaptaciones. Participando en la escena global, compartiendo problemas, buscando la colaboración y creando asociaciones, es sin duda, la estrategia apropiada.

\section{RECONOCIMIENTOS}

Los autores agradecen a:

Los Presidentes, Comités, y miembros de la SPT por su dedicación y su obra de amor para llevar adelante a la sociedad;

Señora Gladys Soruco Shanklin por su excelente coordinación de la oficina de la SPT;

Dres Lucas, Fraga, Morales, Neira, Peitzman, Maull, Fraga, Baqueiro y Peck por sus notas de nuestra historia;

Dr Rodríguez por su visión, apoyo y revisión de este manuscrito

Y al Comité Ejecutivo de la SPT por su revisión y sugerencias valiosas.

\section{REFERENCIAS}

1. Marttos AC, Kuchkarian FM, Abreu-Reis P, Pereira BMT, Collet-Silva FS, Fraga GP. Enhancing trauma education worldwide through telemedicine. World J Emerg Surg. 2012; 7(Suppl 1):S4.

2. Costa CA, Garcia GD, Ginzburg E, Schulman CI, Namias N. Global Connections: Telemedicine as a tool to extend tauma education. Panam J Trauma Critical Care Emerg Surg 2013; 2(1):62-63.

3. Peck GL, Ferrada P, Joseph H, Ferrada R, Christopher D, Ordonez C, Aboutanos M, Gracias V. Can we augment the US trauma fellow's operative training? The PTS fellowship: a US surgical critical care fellow's experience in Colombia Panam J Trauma Critical Care Emerg Surg 2014;3(1):1-7.

4. Ferrada P, Ivatury RR, Spain DA, Davis KA, Aboutanos M, Fildes JJ, Scalea TM. International rotations: a valuable source to supplement operative experience for acute care surgery, trauma and surgical critical care fellows. J Trauma Acute Care Surg 2017 Jan;82(1):51-57.

5. Knuth T. Letter to the Editor. J Trauma 1993;34(6):914.

6. Ferrada P, Ferrada R, Aboutanos M, Ivatury RR. International surgical rotations: a prodigious personal and professional maturation. Am Surg 2015 May;81(5):E230-E231.

7. Ivatury R. Panamerican trauma society travelling scholarship: a cultural, clinical and surgical exchange. Panam J Trauma Crit Care Emerg Surg. 2014;3(1):v.

8. SimõesRL, BermudesFA, AndradeHS, Barcelos FM, RossoniBP, Miguel GP, Fagundes CA, Fraga GP. Trauma leagues: an alternative way to teach trauma surgery to medical students. Rev Col Bras Cir 2014 Jul-Aug;41(4):297-302.

9. Boeck MA, Blair KJ, Foianini E, Perry HB, Mata LV, Aboutanos MB, Haider AH, Swaroop M. Implementation of a hospital-based trauma registry in Santa Cruz de la Sierra, Bolivia: methodology, preliminary results, and lessons learned. Panam J Trauma Crit Care Emerg Surg 2015;5(2):101-112.

10. Uribe A, Roriguez CS, Ordonez, C, Morales M, Ivatury R, Aboutanos M. Reporte del Registro de Trauma de la Sociedad Panamericana de Trauma. Un año de experiencia en dos hospitales de la ciudad de Cali. Panam J Trauma Crit Care Emerg Surg 2015;4(3):109-123.

11. Ordonez CA, Rubiano J, Badiel M, Pino LF, Minan-Arana FD, Tejada JW, Morales M, Puyana JC, Mata L, Aboutanos M, et al. 
Epidemiologia Del Trauma en Dos Hospitales de Primer Nivel de Atencion Del Suroccidente de Colombia. Reporte Preliminar Del Registro Internacional deTrauma de la Sociedad Panamericana de Trauma. Panam J Trauma Crit Care Emerg Surg 2014;3(1):11-15.

12. Calle-Toro JS, Ordonez C, Sanchez AI, Sanjuan J, Badiel M, Pino L, Ivatury RR, Aboutanos M. Epidemiologia de Lesiones Relacionadas con Colisiones Vehiculos Motorizados en dos Centros de Referencia del Suroccidente Colombiano. Reporte del Registro Internacional de Trauma de la Sociedad P. Panam J Trauma Crit Care Emerg Surg 2014;3(1):16-22.

13. Rodriguez CS, Uribe A, Ordonez C, Morales M, Ivatury R, Aboutnaos M. Reporte de la Tendencia del: Trauma Pediátrico en dos Hospitales de Cali en el 2012. Panam J Trauma Crit Care Emerg Surg 2015;4(3):124-135.
14. Ordoñez CA, Morales M, Rojas-MirquezJC, Bonilla-Escobar FJ, Badiel M, Miñán Arana F, González A,Pino LF, Uribe-Gómez A, Herrera MA, et al. Trauma registry of the Pan-American Trauma Society: one year of experience in two hospitals in southwest Colombia. Colomb Med (Cali) 2016 Sep 30;47(3):148-154.

15. Tecker GH. https://www.asaecenter.org/resources/.../sustaining-association success that matters. American Society of Association Executives website. Available from: https:// www.asaecenter.org/resources/articles/an_magazine/2011/ december/Sustaining-association-success-that-matters. Accessed November 11, 2015.

16. Aboutanos M. President's message. Available from: http:// www.panamtrauma.org/president-message. Accessed December 31, 2016. 


\title{
Sociedade Panamericana De Trauma: As Três Primeiras Décadas
}

\author{
${ }^{1}$ Rao R Ivatury, ${ }^{2}$ Michel Aboutanos
}

\section{RESUMO}

A Sociedade Panamericana de Trauma nasceu há 30 anos com a missão de melhorar o atendimento de trauma nas Américas, atraves do intercâmbio de idéias e conceitos e expandindo o conhecimento de trauma e emergencia. Os autores, ex-líderes mais recentes da organização, revisam a evolução deste conjunto de diversas culturas e nacionalidades.

Palavras-chave: History, Sociedade De Trauma, Sociedade Panamericana de Trauma

How to cite this article: Ivatury RR, Aboutanos M. Sociedade Panamericana De Trauma: As Três Primeiras Décadas. Panam J Trauma Crit Care Emerg Surg 2017;6(2):90-123.

Source of support: Nil

Conflict of interest: None

\section{INTRODUÇÃO}

Já fazem trinta anos que a Sociedade Panamericana de Trauma (SPT) nasceu. As três décadas de sua curta existência tem sido bastante movimentada com dores de crescimento, adolescência, maturação e realizações. É um conto interessante de pessoas de várias línguas, nacionalidades, origens e raças se unindo para melhorar o atendimento do paciente traumatizado crítico e do doente cirúrgico no hemisfério. Trata-se de uma jornada de colaboração internacional em cirurgia global e melhorias no atendimento cirúrgico nos países de renda baixa e média. $\mathrm{O}$ alcance da SPT se estende agora a continentes distantes.

O primeiro autor desta comunicação teve o privilégio de participar dessa grande odisseia, primeiro como jovem cirurgião e membro fundador, culminando nos últimos seis anos de diretória executiva. Os autores acabam de terminar seus cargos oficiais de Diretor Executivo e Presidente

\footnotetext{
${ }^{1}$ Professor Emeritus, ${ }^{2}$ Professor

${ }^{1}$ Department of Surgery, VCU Medical Center Richmond VA, USA

${ }^{2}$ Department of Surgery, Director Acute Care Surgical Services VCU Medical Center Richmond, VA, USA

Corresponding Author: Rao R Ivatury, Professor Emeritus Department of Surgery, VCU Medical Center, W 15E, 1200 East Broad Street, Richmond, VA 23298, USA, e-mail: raoivatury@ gmail.com
}

da Sociedade, respectivamente. O objetivo deste relatório é documentar a jornada da Sociedade desde sua infância até o estado atual da idade adulta. A intenção não é nem um pouco de auto-engrandecimento, mas de tecer a evolução de uma sociedade multinacional na era atual de maior entusiasmo por questões de cirurgia global. É um tributo para os muitos e muitos membros individuais, membros do Conselho Diretor, dos Comitês e ex-Presidentes que coletivamente devem ser creditados com a atual posição da Sociedade. Esperamos sinceramente que os membros leiam esta história, orgulhosamente tomem posse desta Sociedade como se fosse sua e inspirem outros a leva-la adiante. Que este documento também sirva como o bastão para a geração e liderança vindouras.

\section{O NASCIMENTO}

A SPT foi concebido durante um almoço, em um restaurante na Cidade do México chamado "Hacienda Los Morales" em 1987, durante um simpósio da Cruz Vermelha Mexicana. Foi um pensamento inspirado do Dr Armando Baqueiro, do México, que propôs criar uma Sociedade com a missão de melhorar o atendimento de pacientes de trauma no Hemisfério Americano: Norte, Central e Sul e, conseqüentemente, chegamos ao nome de SPT. Os visionários incluíram os Drs Baqueiro, Aurelio Rodríguez, Alejandro Grife, Garcia Morales "El Max", Gomez Palacio, Carlos Moreno - todos cirurgiões latino-americanos de experiência e prestígio (Foto 1). Os Drs Aurelio Rodriguez e Francisco Holguin (da Colômbia) percorreram o mundo latino-americano, apresentando a proposta de criar esta Sociedade. A idéia teve aprovação unânime. A Sociedade foi fundada oficialmente em Bogotá, Colômbia, em 1989. Os primeiros dirigentes e membros se reuniram durante o Congresso Anual da Federação das Sociedades Cirúrgicas da America Latina no Equador e naquela época o Dr Aurelio Rodriguez do Peru e dos EUA foi nomeado como o primeiro presidente, e Ricardo Sonneborn do Chile como primeiro vice-presidente.

\section{A INFANCIA}

O primeiro Congresso Anual da SPT foi realizado em San Juan, Porto Rico em 1988 com a benevolência econômica

Esta es una versión ampliada del artículo publicado en el Journal of Trauma and Acute Care Surgery, 2017 mayo; 82(5):966973 bajo la licencia de acceso abierto de CC-BY-NC-ND 




Foto 1: O "almoço de inspiração" onde foi proposta a SPT Da esquerda a direita: Drs: Gomes-Palacios, Carlos Moreno, Armando Baqueiro, Aurelio Rodriguez, Alejandro Grife. Falta: Garcia Morales "el max"

de seu Governador. Foi realizada uma definição mais abrangente do Conselho Diretor. O segundo Congresso estava prestes a acontecer em 1989, em Porto Rico. Havia, entretanto, um invasor indesejado na forma do furacão Hugo. O Congresso nunca se materializou. Felizmente, tanto a Sociedade e os visitantes retidos pelo furacão sobreviveram a esta adversidade. A segunda assembléia científica da Sociedade foi realizada no ano seguinte em São Paulo, Brasil. O grupo brasileiro, liderado pelo distinto Professor Dario Birolini e seu grupo do Hospital das Clínicas juntou-se à SPT. A colaboração brasileira é forte até hoje. O terceiro Congresso, em Buenos Aires, Argentina, foi realizado após da primeira assambleia de um recém-formada Associação de Trauma da Colômbia em Bogotá, Colômbia. Desde aquela época, a SPT amadureceu e um Congresso foi realizado anualmente no mês de Novembro, em varios países (Caixa 1). Os três membros não-americanos majoritários da SPT - Brasil, Colômbia e Argentina - e seus delegados, incluindo os professores Birolini, Holguin, e Rasslan - foram os primeiros pioneiros. Apoio Norte Americano de peso veio dos primeiros líderes : Professores Rodriguez, Mulder e Ernest Moore. Professores Feliciano, Hoyt, Maull, Mattox, Maier, Frykberg, Baker, e Briggs dos EUA, Gutierrez e Neira da Argentina, Tovar do México, e muitos outros serviram para amadurecer a SPT.

Os Congressos anuais da SPT ganharam reputação internacional com a participação de profissionais de saúde - líderes em Trauma e Cuidados Intensivos de todo o mundo. A Sociedade celebrou seu aniversário de prata (25 anos) em 2015, em Medellín, Colômbia, em uma exibição orgulhosa da ciência e da cultura, com a maioria dos presidentes presentes. A participação, como tem sido habitual para a SPT, envolveu não apenas cirurgiões (e cirurgiãs), mas também médicos(as) de emergência,
Caixa 1: Reuniões anuais
1987 Primeira Reunião do Conselho, Quito, Equador
1988 Primeiro Congresso da SPT, Porto Rico
1990 São Paulo, Brasil
1991 Buenos Aires, Argentina
1992 Guadalajara, México
1993 San José, Costa Rica
1994 Cartagena, Colômbia
1995 Salvador, Brasil
1996 Cartagena, Colômbia
1997 Miami, EUA
1998 Buenos Aires, Argentina
1999 Margarita, Venezuela
2000 Panamá, Panamá
2001 Monterrey, México
2002 São Paulo, Brasil
2003 Lima, Perú
2004 Miami, EUA
2005 Guayaquil, Equador
2006 Cartagena, Colômbia
2007 Puebla, México
2008 Campinas, Brasil
2009 Caracas, Venezuela
2010 Montevideo, Uruguay
2011 Asunción, Paraguay
2012 Medellín, Colômbia
2013 Santiago, Chile
2014 Panamá City, Panamá
2015 Santa Cruz, Bolivia
2016 Maceió, Brasil

internistas, enfermeiros(as), paramédicos(as), residentes e estudantes de medicina. A SPT acaba de concluir um congresso bem sucedido em conjunto com a Sociedade Brasileira de Atendimento Integrado ao Traumatizado (SBAIT) en Maceió, Brasil, em 2016.

\section{DIRETORES DA SPT}

À medida que a Sociedade estava crescendo e saindo de sua infância, a diversidade multi-nacional e multicultural da organização se tornou um pilar proeminente de força e um traço universalmente admirado. Todos os países da América do Sul e suas organizações de trauma e de cirurgia começaram a participar e contribuir para a missão conjunta da Sociedade. Onde nada existia, houve um novo entusiasmo de se formar organizações locais e se associar à SPT. Muito cedo, a Sociedade decidiu alternar a Presidência entre reconhecidos cirurgiões(e cirugiãs) norte-americanos e sul-americanos, e a tradição continua até hoje (Anexo 1 e Foto 2).

Cada um desses líderes, ao longo das últimas três décadas, reforçou a missão comum, enfatizou nossa identidade no meio da diversidade, definiu metas futuras para a Sociedade e inspirou o crescimento contínuo. Os Presidentes são assistidos em suas funções e 


\begin{tabular}{|c|c|c|c|c|}
\hline Ano & Cidade & Presidente & Discursante da Palestra & Tema: Palestra Aurelio Rodriguez \\
\hline 1988 & San Juan, Porto Rico & A Rodríguez, (EUA) & & \\
\hline 1990 & São Paulo, Brasil & A Rodríguez (EUA) & & \\
\hline 1991 & Buenos Aires, Argentina & F Holguín (Colômbia) & & \\
\hline 1992 & Guadalajara, México & E Moore, (EUA) & & \\
\hline 1993 & San Jose, Costa Rica & D Birolini (Brasil) & & \\
\hline 1994 & $\begin{array}{l}\text { Cartagena de Indias, } \\
\text { Colômbia }\end{array}$ & C Lucas (EUA) & & \\
\hline 1995 & Salvador, Brasil & A Baqueiro (México) & & \\
\hline 1996 & $\begin{array}{l}\text { Cartagena de Indias, } \\
\text { Colômbia }\end{array}$ & K Maull (EUA) & & \\
\hline 1997 & Miami, EUA & R Ferrada (Colômbia) & & \\
\hline 1998 & Buenos Aires, Argentina & G Gomez (EUA) & & \\
\hline 1999 & $\begin{array}{l}\text { Isla Margarita, } \\
\text { Venezuela }\end{array}$ & D Ortega (Perú) & & \\
\hline 2000 & $\begin{array}{l}\text { Ciudad de Panamá, } \\
\text { Panamá }\end{array}$ & D Feliciano (EUA) & & \\
\hline 2001 & Monterrey, México & $\mathrm{J}$ Neira (Argentina) & & \\
\hline 2002 & São Paulo, Brasil & R Ivatury (EUA) & Ricardo Ferrada (Colômbia) & Education and Trauma \\
\hline 2003 & Lima, Perú & S Rasslan (Brasil) & $\begin{array}{l}\text { Gerardo Gomez (EUA / } \\
\text { Venezuela) }\end{array}$ & Sepsis, what is new? \\
\hline 2004 & Miami, EUA & S Briggs (EUA) & Donald Trunkey (EUA) & $\begin{array}{l}\text { Violencia, Drogas y Trauma en el } \\
\text { Hemisferio Occidental: Una solución } \\
\text { alternativa. }\end{array}$ \\
\hline 2005 & Guayaquil, Ecuador & J Lombardi (Chile) & Ernest Moore (EUA) & Blood substitutes in Trauma \\
\hline 2006 & $\begin{array}{l}\text { Cartagena de Indias, } \\
\text { Colômbia }\end{array}$ & D Hoyt (EUA) & C. Willam Schwab (EUA) & The winds of war \\
\hline 2007 & Puebla, México & C Morales (Colômbia) & Jorge Neira (Argentina) & $\begin{array}{l}\text { Nuevos aspectos en la resucitación } \\
\text { de volumen en la atención inicial del } \\
\text { paciente traumatizado }\end{array}$ \\
\hline 2008 & Campinas, Brasil & A Peitzman (EUA) & Raul Coimbra (EUA/Brazil) & $\begin{array}{l}\text { Trauma as a Disease: The public's } \\
\text { perception }\end{array}$ \\
\hline 2009 & Caracas, Venezuela & J Garcia (Venezuela) & Renato S. Poggetti (Brazil) & Trauma prevention \\
\hline 2010 & Montevideo, Uruguay & R Coímbra (EUA) & Ronald Maier (EUA) & $\begin{array}{l}\text { Molecular and genetic aspects of the } \\
\text { response to trauma }\end{array}$ \\
\hline 2011 & Asunción, Paraguay & R Pogetti (Brasil) & Armando Baqueiro (México) & $\begin{array}{l}\text { The evolution of teaching and } \\
\text { management of Trauma in Mexico in } \\
\text { the last } 25 \text { years }\end{array}$ \\
\hline 2012 & Medellín, Colômbia & J Puyana (EUA) & Ethan Nadelmann (EUA) & Why we need to end the war on drugs \\
\hline 2013 & Santiago, Chile & A Pacheco (Chile) & Ricardo Sonneborm (Chile) & Origin and destination in trauma \\
\hline 2014 & $\begin{array}{l}\text { Ciudad de Panamá, } \\
\text { Panamá }\end{array}$ & M Lorenzo (EUA) & Stanley Motta (Panamá) & Why trauma? A personal experience \\
\hline 2015 & Santa Cruz, Bolivia & G Fraga (Brasil) & Rao Ivatury (EUA) & PTS: a look back and a look forward \\
\hline 2016 & Maceio, Brazil & M Aboutanos (EUA) & Thomas Scalea (EUA) & $\begin{array}{l}\text { Mentoring the future Trauma Leaders: } \\
\text { Implications for the Panamerican } \\
\text { Trauma Society }\end{array}$ \\
\hline
\end{tabular}

responsabilidades por um Diretor Executivo. Estes dois diretores mais altos da organização e sua parceria próxima tem sido uma receita essencial para o sucesso da sociedade. As pessoas que já tiveram o privilégio desta posição são: os Drs Rodriguez, Holguin, Gómez, Maull, Peitzman e Ivatury. O Dr Scalea é o recem-eleito diretor executivo e assumiu o cargo desde novembro de 2016. Com um Conselho de Diretores jovem e disposto e um SecretárioTesoureiro de entusiasmo e energia infatigáveis, a SPT fez avanços rápidos em recrutar membros e manter a dinâmica fluindo. Os Drs Barba, Gomez, Peitzman, Puyana e
Aboutanos merecem um imenso crédito por seus incansáveis esforços como secretários-tesoureiros para trazer a Sociedade para o século XXI. O Secretário atual, Esteban Foainini, está seguindo esses exemplos eminentes.

\section{ESCRITÓRIOS SEDE DA SPT}

Inicialmente instalado em Baltimore, graças ao apoio do Dr RA Cowley do Shock Trauma Center, o escritorio sede foi mudado para Connecticut com um novo secretário. O ano 2003 foi revolucionario, quando o Dr Peitzman levou a Sociedade para a Universidade de Pittsburgh e nutriu-a 



Foto 2: Presidentes da SPT 1987-2016

Linha 1 (da esquerda a direita): A.Rodriguez (EUA), 1987-1989; D Mulder (Canadá), 1989-1990; E Moore (EUA), 1990-1991; F Holguin (Colômbia), 1991-1992, D Birolini (Brasil), 1992-1993; C Lucas (EUA), 1993-1994; A Baqueiro (México), 1994-1995; K Maull (EUA), 1995-1996

Linha 2 (da esquerda a direita): R Ferrada (Colômbia), 1996-1997; G Gomez (EUA), 1997-1998; D Ortega (Peru); 1998-1999, D Feliciano (EUA), 1999-2000; J Neira (Argentina), 2000-2001; R Ivatury (EUA), 2001-2002; S Rasslan (Brasil), 2002-2003

Linha 3 (da esquerda a direita): S Briggs (EUA), 2003-2004; J Lombardi (Chile) 2004-2005; D Hoyt (EUA), 2005-2006; C Morales (Colômbia), 2006-2007; A Peitzman (EUA), 2007-2008; J Garcia (Venezuela), 2008-2009; R Coimbra (EUA), 2009-2010

Linha 4 (da esquerda a direita): R Pogetti (Brasil) 2010-2011; J Puyana (EUA), 2011-2012; A Pacheco (Chile), 2012-2013; M Lorenzo (EUA), 2013-2014; G Fraga (Brasil) 2014-2015; M Aboutanos (EUA), 2015-2016, C Ordonez (Colômbia), 2016-2017

pelos próximos 7 anos. Sob a liderança dos Drs Peitzman (como Secretário, Presidente e Diretor Executivo) e Puyana (como Secretário e, em seguida, como Presidente), a SPT viu enormes avanços no recrutamento de sócios, na manutenção de registros, na racionalização dos cursos educacionais da SPT assim como na atualização do website da Sociedade.

Em 12 de novembro de 2010, o escritório sede foi transferido de Pittsburgh para o local atual em Richmond, [Virginia] na Divisão de Serviços Cirúrgicos de Emergencia, Departamento de Cirurgia, Virginia Commonwealth University (VCU) com uma excelente administradora, Sra. Gladys Shanklin. A SPT e a VCU, sob a benevolência do Presidente Michael Rao e o Reitor Jerry Strauss, entraram em uma parceria na qual a universidade fornece assistência financeira significativa para o escritório sede da SPT e seu pessoal, e fornece Educação Médica Continuada (CME) para os congressos da SPT. O Presidente da VCU, juntamente com o Reitor, e os líderes do Departamento de Cirurgia - Drs Neifeld e Kasirajan - participaram dos Congressos da SPT em 2012 e 2015, solidificando a relação. Em 2016, a Faculdade de Medicina VCU formalmente assinou um contrato (Memorandum of Understanding) com a SPT para continuar a fornecer apoio financeiro de mais de 250 mil dolares por ano, por mais três anos.

\section{MATURAÇÃO DA VISÃO DA SPT}

Na última década, a SPT amadureceu e entrou na fase adulta. Onde anteriormente era uma organização focada na pratica clinica, ela agora voltou seu foco para sistemas de trauma. Era uma sociedade centrada no congresso, mas agora se tornou uma sociedade com um Congresso. Era uma sociedade nômade com migrações frequentes, mas agora é uma Sociedade baseada em universidade. Neste processo de maturação, ela definiu um caminho para alcançar a independência financeira e tornar-se solvente. A seguinte narrativa tentará ilustrar alguns elementos deste progresso.

\section{Serviços de Afiliação:}

Desde 2015, o número de membros da Sociedade atingiu 27 países (21 países da América Latina e do Caribe: Argentina, Bolívia, Brasil, Canadá, Chile, Colômbia, 
Costa Rica, Cuba, Curaçao, Equador, El Salvador, Guatemala, Nicarágua, Panamá, Paraguai, Peru, Estados Unidos, Uruguai, Venezuela) (e 6 outros países - Angola, Finlândia, Qatar, Holanda, Noruega, Espanha). Esforços ativos estão em andamento para aumentar o numero de membros sob a iniciativa da presidente do Comite, Dra. Jimenez.

\section{Website da SPT}

A SPT viu avanços significativos no desenvolvimento do seu website sob a liderança dos Drs Peitzman e Puyana (2003-2010). Com a transferência da sede da SPT para Richmond, Virgínia em 2010, uma decisão crucial foi feita para tornar o website da SPT independente doservidor da Universidade e seus "firewalls" obrigatórios. Isto permitiu um avanço exponencial na funcionalidade do site no servico para os membros da SPT. Ele forneceu um sistema automatizado para alternar entre os seus três idiomas (Inglês, Espanhol e Português); um sistema automatizado de comunicação (2011); um sistema automatizado de pagamento on-line (2012); um sistema automatizado on-line para submissão de resumos, competicao de pesquisa e um sistema de avaliação (2013). Uma plataforma de compartilhar e receber vídeos baseada em Vimeo (2014) foi desenvolvida com a ajuda do ex-vicepresidente Daniel Ludi. Este recurso disponibiliza uma miríade de palestras de lideres especialistas em trauma e atendimento de emergência. Melhorias recentes incluem Educação Médica Coninuada on-line, uma exibição de dispositivos móveis, um centro de notícias, e links de mídia social (2015-16).

\section{A agenda Educativa da SPT}

A missão compartilhada dos membros da SPT é melhorar o atendimento dos pacientes críticos ou traumatizados nas Américas, especialmente na América do Sul. A Sociedade pretende alcançar este objectivo atraves da sua constante ênfase na educação médica contínuada e na colaboração, com um comitê energético sob a direcção da Dra. Paula Ferrada.

A SPT acredita que as melhorias no cuidado do paciente traumatizado ou critico, mesmo nos países com recursos limitados como os países de baixa a média renda, são viáveis e dependem da organização e planejamento. A SPT argumenta que a educação ea aprendizagem baseada na prática através de todos os seus cursos terão um impacto positivo na gestão do paciente. O numero total de cursos foi de 136 entre 2010-2015, muitos deles por meio do SBAIT. Incluíram: Habilidades Cirúrgicas em Trauma (DQT), Ultra-som em Emergência e Trauma (USET) básico, USET Avançado, Curso Avançado de Resposta a Desastres Médicos (ADMR), Curso de
Melhoria de Qualidade da Organização Mundial de Saúde (OMS), Curso Básico de Trauma para Médicos Rurais / Enfermeiros / Pessoal pré-hospitalar, Curso de Queimaduras, Curso de Enfermagem, Curso de Resgate Médico Aéreo e Curso Pré-hospitalar, entre outros. Esses cursos são padronizados e propagados pelo uso da tecnologia da informação (website) e também pelas mídias sociais. A demanda por esses cursos está aumentando em toda a América Latina, pois são projetados especialmente para os profissionais e prestadores de cuidados de saúde em países de baixa a média renda e são mais acessíveis do que os cursos europeus ou americanos.

\section{A Palestra Aurelio Rodríguez}

Iniciada em 2002 e apresentada no congresso anual com convite do Presidente, foi criada para homenagear o fundador, visionário e líder da SPT. É um tributo a sua presença, contribuições e participação que proporcionam a "cola" que mantem a sociedade unida. A palestra, em um tópico contemporâneo, logo se tornou um destaque do congresso e é altamente valorizada tanto pelo conferencista como pelo público. Estas palestras estão listados na Tabela 1.

\section{Envolvimento das sociedades locais}

A próxima iniciativa da SPT é envolver as sociedades locais e ajudá-las a organizar atividades educacionais, oferecendo cursos da SPT a preços reduzidos e fornecendo ajuda com o corpo docente e materiais didaticos. A SPT também atua como organização-mãe para várias organizações focadas em traumas no México, Equador, Colômbia, Panamá, Bolívia, Peru, Paraguai, Uruguai, Brasil e Argentina.

\section{Exposição de pesquisas e publicações na América do Sul}

É de conhecimento geral que o cuidado de trauma e doenças cirúrgicas é esmagadoramente complexo em sua incidência e gravidade nesses países, apesar dos sul-americanos serem reconhecidos por sua imensa experiência nestas areas. Além da habilidade cirúrgica que esta experiência lhes traz, eles desenvolveram muitas soluções inovadoras e de baixo custo na sua prática clínica apropriada às suas próprias condições econômicas. Grandes exemplos incluem a bolsa do Borraez (Bogotá) para fechamento temporário do abdomen da Colômbia, o pacote do Pogetti (para compressão interna dos trajetos de bala no fígado) do Brasil e o primeiro reparo endovascular do aneurisma da aorta abdominal (Parodi, Buenos Aires). Muitos destas eletrizantes criações ocorrem todos os dias na América do Sul e a SPT fornece a esses inovadores uma avenida para mostrar seus talentos em 


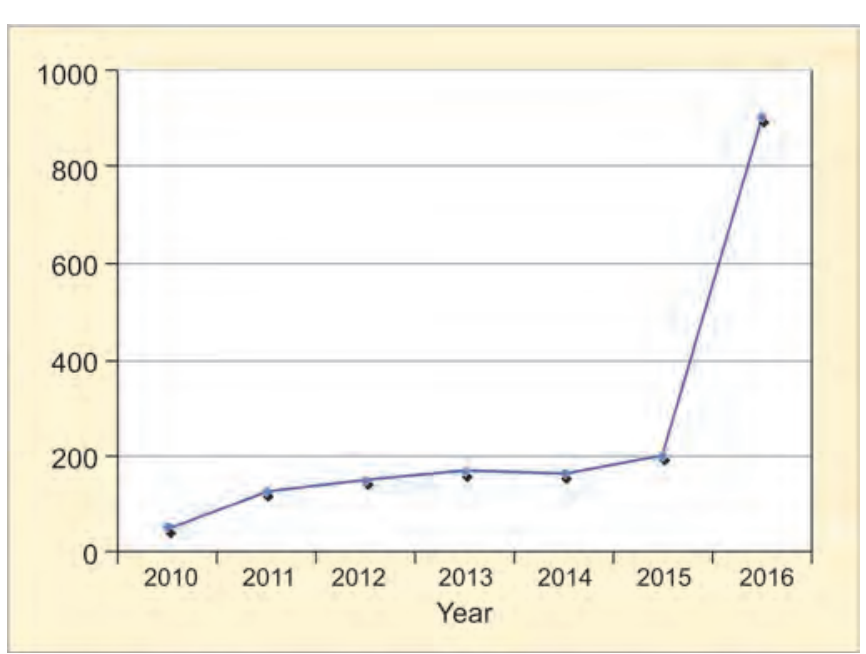

Figura 1: Número de resumos enviados para participar no congreso anual (2010-2016)

Congressos e publicações (Jornal oficial da Sociedade, livros texto, etc ...)

\section{Concursos SPT de Pesquisa}

Os concursos de pesquisa, realizadas anualmente no Congresso da SPT para médicos, residentes e estudantes testemunharam um enorme crescimento nos resumos cientificos submetidos ao Congresso nos últimos 5 anos (Figura 1). Houve um recorde de 900 resumos em 2016, levando a 80 apresentações orais e 300 apresentações mini-orais no congresso. Uma sessão inteira foi dedicada à prevenção de trauma.

Coincidentemente, o número de manuscritos submetidos ao Jornal da Sociedade, The Panamerican Journal of Trauma, Critical Care and Emergency Surgery (PAJTCCES) tem escalado com uma constante, notável melhoria na qualidade.

As bolsas de viagem para os resumos vencedores são doações fornecidas pela ex-presidente Susan Briggs, relacionadas com a gestão de desastres e na área de prevenção, do ex-presidente Michel Aboutanos e o Dr Terrence O'Keefe: brilhantes exemplos de inspiração. Impressionantemente, o atual presidente, Carlos Ordóñez, e sua equipe de Cali têm se destacado em colocar seus resumos científicos com sucesso nas apresentações orais extremamente competitivas do congresso científico anual do AAST. Seu recorde recente de múltiplas publicações em revistas internacionais estabeleceu novos padrões para a SPT.

\section{Publicações da SPT}

A SPT é ativa na publicação de livros texto, manuais e guias escritos por seus membros. Muitos deles tiveram os direitos autorais transferidos para a SPT. Os exemplos incluem: TRAUMA, (o livro texto oficial daSPT, atualmente passando por uma revisão com uma nova edição que estará disponível tanto em papel impresso como e-book electrônico, esperado para 2017); Guidelines for Trauma Quality Improvement Programs (Diretrizes para Programas de Melhoria da Qualidade de Trauma) (juntamente com a OMS) - disponível em inglês e português; Manuais de USET Advanced em espanhol; USET e ADRM - em português e espanhol; Burn (Queimados) - espanhol. Outras publicacoes pelos membros da SPT foram traduzidos para o espanhol, incluindo: Abdominal Compartment Syndrome; Trauma Manual; US in the ICU; Cuidado Intensivo Y Trauma e Guías de Desarrollo de Sistemas de Trauma y Cuidados Esenciales de Trauma para América Latina.

\section{A Revista}

ASPT tem mantido por muito tempo sua propria revista, o Panamerican Journal of Trauma, sob a redação do Dr Ricardo Ferrada. Depois de um hiato em 2009, o Jornal foi retomado em 2012 com um novo conselho editorial sob a redação do Dr Rao Ivatury e Jaypee publicadores da Índia. Publicado trimestralmente como uma publicação eletrônica, cobre todos os aspectos de trauma, cuidados intensivos e cirurgia de urgência. Ela aspira a ser um canal onde todos os membros da SPT podem mostrar sua vasta experiência clínica e a revista esta tendo sucesso nesta missão. Mais importante, ela se tornou um recurso para a nova geração de estudantes de medicina, residentes e novos cirurgiões nos seus esforços de iniciar publicações científicas. Ela também se tornou um canal para a publicação de artigos apresentados nas competições de pesquisa do congresso anual. $\mathrm{O}$ conselho editorial promete continuar a atrair a investigação clínica, com base no material abundante que é fornecido aos membros da SPT, e também promete continuar a encorajar jovens cirurgiões e aqueles em treinamento a publicar. A indexação da Medline pela National Library of Medicine (Biblioteca Nacional de Medicina) é um objetivo vital que esperamos poder alcançar este ano.

\section{Reuniões Internacionais via Telemedicina}

O Dr Antonio Marttos e a Universidade de Miami/Ryder Trauma Center criaram reuniões clínicas internacionais via telemedicina, com apresentações semanais de casos transmitido via telemedicina e discutido por cirurgiões de trauma de todo o mundo. Através de videoconferência, apresentações complexas de casos de trauma, trauma avançado, e tópicos de cuidados críticos são discutidos semanalmente. As apresentações de casos proveem a estudantes, residentes, fellows e médicos uma excelente ferramenta para educação e compartilhamento de conhecimentos médicos atraves de fronteiras. Créditos de educação médica contínua (CME) estão 
disponíveis para médicos elegíveis. Até o momento, 42 instituições ja participaram, incluindo: Estados Unidos, Brasil, Colômbia, Bahamas, Haiti, Canadá, Venezuela, Argentina, Panamá, Porto Rico, República Dominicana, Ilhas Virgens Britânicas, Espanha, Tailândia, Turquia e Iraque; extendendo desde centros médicos acadêmicos até centros urbanos de trauma, hospitais militares, comunitários e rurais. ${ }^{1,2}$ A SPT adotou essas reuniões clínicas internacionais como uma de suas atividades educacionais. Em um acordo acadêmico, essas reuniões são anunciadas no website da AAST para informação e participação. Esforços estão em curso para converter alguns destas reunioes em publicações plenas no Journal of Trauma and Acute Care Surgery.

\section{Fellowships e Bolsas de Estudo Internacionais}

A SPT se envolveu na facilitação de oportunidades para jovens residentes em treinamento, bem como jovens cirurgiões para fazer uso do tremendo material clínico disponível na América do Sul e Central e da ciência e arte de sistemas de trauma nos EUA. ${ }^{3,4} \mathrm{O}$ objetivo do fellowship é melhorar a formação cirúrgica de bolsistas e das instituicoes anfitreas de experimentar pesquisa e intercâmbios.

Aqueles proveniente da America do Norte são beneficiados pela coordenação de sua visita a um centro de excelência na América do Sul ou Central, com um perito local que hospeda a visita, com a SPT fornecendo opções para hospedagem, viagem e logística. Alguns dos vencedores recentes desta bolsa internacional incluem residentes da Universidade do Leste da Carolina, Universidade de Miami, Universidade Emory e Universidade de Indiana. Outros exemplos incluem uma bolsa de viajem para a Bolívia para trabalhar no Registro de Trauma da SPT (descrito abaixo), ou viajando para treinar em ultra-som em Cuba. Estas oportunidades de bolsas internacionais receberam financiamento de doações generosas de membros individuais (como Paula Ferrada), e organizações como Post-Graduate Fellowship in Global Health at Northwestern University Feinberg - SOM's Center for Global Health (Bolsa de Pós-Graduação em Saúde Global da Northwestern University Feinberg, Centro de Saúde Global da Escola de Medicina), sob a orientação do Dr Mamta Swaroop.

Em contrapartida, as instituições que receberam estes bolsistas na America Latina desenvolvem relações com instituições norte-americanas, proporcionando oportunidades de cambio e promovendo pesquisas e programas colaborativos. As instituições norte-americanas fornecem o Programa de Observadores Internacionais da SPT, descrito abaixo, bem como uma bolsa internacional de pesquisa. Esta bolsa tem como objetivo oferecer aos aspirantes a cirurgiões-cientistas de trauma da America latina a oportunidade de treinamento em pesquisa em serviços de saúde e desenvolvimento profissional nas instituições norte-americanas. Exemplos incluem um vencedor da bolsa de viagem para a Bolívia, viajando para treinar em ultra-som em Cuba, um pesquisador do The Center for Surgery and Public Health (CSPH) at Brigham and Women's Hospital (Centro de Cirurgia e Saúde Pública (CSPH) no Brigham e Women's Hospital) sob a orientação do Dr Adil Haider, focando em resultados funcionais e recuperação após emergências traumaticas.

Esatgioes de curta duracao (3 a 6 semanas) também estão disponíveis para médicos, enfermeiros, paramédicos e estudantes sul-americanos para visitar centros de trauma nos EUA para observar, auditar e experimentar o desenvolvimento e o funcionamento dos sistemas de trauma, as nuances nas atividades de melhora da qualidade e desenvolvimento de equipes e gerenciamento no cuidado dos pacientes traumatizados ou criticamente enfermos. Este Programa Internacional de Observacao está aberto a membros estrangeiros qualificados que desejam visitar e observar certas atividades clínicas e educacionais nos centros de trauma afiliados. Apenas no VCU, um total de 19 observadores (desde médicos clínicos gerais atefellows de trauma) aproveitaram esta oportunidade, vindo de países como Colômbia, Brasil, México, Chile, Equador e Sudão.

Outros centros, como a Universidade de Pittsburgh Medical Center e Alleghany Medical Center (Pensilvânia), Riverside County Regional Medical Center (Califórnia) e Universidade de San Diego, Universidade de Southern California, e a Universidade de Indiana também estão ativamente envolvidas. ASPT e suas 18 sociedades afiliadas, e universidades como a Universidad del Valle (Universidade do Valle) em Cali, Colômbia, oferecem exemplos notáveis. Desde 2011, seus fellows de Trauma e Cirurgía de Emergencia tiveram a oportunidade de fazer um estágio de três meses na Virginia Commonwealth University (VCU) e também na Universidade de Pittsburgh.

No passado, muitos bolsistas da R Adams Cowley Shock Trauma Center em Baltimore, Maryland, bem como estagiariosde Israel e outras partes do mundo passaram um mês sob a tutela do Dr Ricardo Ferrada em Cali, Colômbia, para receber um enorme experiência de casos desafiadoras de trauma. Testemunhos incandescentes dessa experiência foram relatados por Knuth, Ferrada e outros. ${ }^{5-7}$

\section{Programa de Intercâmbio Paramédico}

A ênfase no atendimento pré-hospitalar, treinamento e desenvolvimento na região da América Latina tornou-se uma importante missão da sociedade, portanto criamos: um subcomitê dedicado ao pré-hospitalar, cursos pré-hospitalares, sessões pré-hospitalares no congresso anual e o 
programa de Intercâmbio de Paramédicos. Em 2014, The Virginia Association of Volunteer Rescue Squads - VAVRS (a Associação de Esquadrões de Salvamento Voluntários da Virgínia) e a SPT, sob a liderança de Jane Laverne (EUA) e o Dr Andres Rubiano, Presidente do Comité Pre hospitalar da SPT, desenvolveram um Programa de Intercâmbio Pré-Hospitalar entre o pessoal pré-hospitalar do estado da Virginia e o pessoal pré-hospitalar de varias cidades da Colômbia. O resultado foi uma troca recíproca de paramédicos que compartilharam conhecimento inestimável de primeira mão e experiência e treinamento tatico em resposta de emergência em ambientes diferentes - tanto em paises de renda alta quanto baixa ou média. Essas trocas foram reforçadas por estagios dedicados de curta com a Autoridade de Ambulância de Richmond e o Escritório Estadual de Serviços Médicos de Emergência da Virgínia.

\section{Educação de Enfermagem}

Desde o início, a SPT tem dedicado um enorme respeito ao campo de enfermagem, reconhecendo-o como um importante membro da equipe. Os primeiros pioneiros da seção de enfermagem da SPT, como Mary Beachley do Maryland Institute of Medical Sciences (Instituto de Ciências Médicas de Maryland e Vivian Lane de Connecticut, realizaram atividades educacionais muito bem sucedidas para enfermeiras durante os Congressos da SPT. Cristiane de Alencar Domingues, de São Paulo, Brasil, está liderando o componente de enfermagem da SPT com energia e entusiasmo.

ASPT, juntamente com Rutgers Robert Wood Johnson Medical School (a Escola de Medicina da Rutgers Robert Wood Johnson, Rutgers School of Nursing (Escola de Enfermagem da Rutgers e Robert Wood Johnson University Hospital-RWJUH (o Hospital Universitário Robert Wood Johnson), apoiada por uma bolsa do Rutgers Centers for Global Advancement and International Affairs (Centro Rutgers para o Avanço Global e Assuntos Internacionais, organizou um simpósio global de enfermagem em Nova Jersey, EUA, em junho de 2016 sob a liderança do Dr Peck. Consuelo Burbano, da Universidade de Valle da Colombia, e Lisa Falcon e Sue Willard, da Universidade de Rutgers, forneceram uma visão global dos conceitos em sistemas de trauma, focando especificamente no desenvolvimento de uma posicao como Gerente de Enfermagem de Trauma. O esforço da SPT, liderado por Cristiane de Alencar Domingues, Gaspar Reboredo e Jasmine Garces, organizou cursos de enfermagem em trauma para seis enfermeiras participantes do Quênia e Colômbia durante o simpósio. Este é um excelente exemplo de parcerias acadêmicas entre universidades americanas de alta renda que compartilham com as missões comuns de assistência cirúrgica da SPT na América Latina. O simpósio de 2017 esta atualmente sendo planejado para o mês de março.

\section{Ligas do Trauma}

As ligas acadêmicas surgiram no Brasil como uma experiência de ensino no início da década de 1990, composta de associações de alunos sob a orientação de um professor supervisor. Iniciado pelo Dr Mario Mantovani, em Campinas, e nutrido pelo ex-presidente da SPT, Gustavo Fraga, a Liga do Trauma da Unicamp (Universidade de Campinas), UNICAMP e outras 9 Ligas do Trauma formaram o Congresso Brasileiro das Ligas do Trauma CoBRaLT), a maior das Ligas do Trauma, que em 1999 realizaram o Congresso Brasileiro das Ligas do Trauma (CopBRaLT), o maior das ligas do Trauma. Eles focam em conceitos de trauma e atendimento de emergência e expõem os alunos ao Pronto Socorro, centro cirurgico e áreas de atendimento pré-hospitalar e também estimulam o interesse pelo trauma como carreira. ${ }^{8} \mathrm{~A}$ CoBRaLT é o comitê central de todas as Ligas do Trauma no Brasil, representando e coordenando-as em todos os aspectos de trauma e Cirurgia de Urgência. Ela organiza o encontro anual do Congresso Brasileiro das Ligas do Trauma, reunindo mais de 800 estudantes de medicina de diferentes escolas. Ligas similares foram iniciadas nos EUA (Pittsburgh e Richmond).

Em 2013, foi criada a primeira liga equatoriana de trauma e emergência (LATE) com o apoio de 2 universidades; Universidad del Azuay e Universidad de Cuenca, na cidade de Cuenca, Equador. Isto coincidiu com a inauguração de um novo Serviço Médico de Emergência (SIS ECU 911) e o desenvolvimento de novas tecnologias do Centro de Trauma e Emergência do Hospital Vicente Corral Moscoso (HVCM). Em 2013, o LATE teve 40 alunos e 4 orientadores trabalhando em quatro áreas principais: prevenção e promoção no campo de trauma, educação medial, investigação e uma comite de disciplina e controle. O entusiasmo do LATE foi evidenciada pelo número de alunos que queriam pertencer (113 em 2013 e 400 em 2014). Apenas 45 e 42 foram admitidos, respectivamente! Os membros atuais totalizam 80 - que foram responsáveis por 28 projetos bem-sucedidos, incluindo: workshop de Sutura e bloqueio anestésico e Primeiros Socorros em Trauma, curso básico de trauma da SPT, "Respeito à chamada 911" para evitar chamadas falsas aos Serviços de Emergência Médica, "torne-se um doador de sangue", educando os alunos do ensino médio sobre o papel do primeiro respondente (612 alunos). Outras realizações incluíram: extensção para cerca de 5.000 pessoas, cinco publicações, 16 cursos de formação, 14 Campanhas de promoção, 10 apresentações orais, três Bolsas de viagem internacional da SPT (2014, 2015 e 2016); primeiro lugar 
na apresentação oral do congresso Panamericano da SPT em 2013 e 20 projetos de pesquisa (17 concluídos).

Colômbia é o país mais recente vendo a ascensão das ligas do trauma entituladasLiga do Trauma e Emergências do Pacífico. Elas estão localizados em Cali sob a direção da Fundação Valle de Lili e atual presidente da SPT, o Dr Carlos Ordonez. Tem mais de 50 estudantes de medicina, todos eles membros da SPT.

O corpo de alunos das Ligas do Trauma esta crescendo não apenas em número, mas também na participação em congressos locais e internacionais com a melhoria da qualidade da participação acadêmica. É certo que as Ligas do Trauma não são uma iniciativa original da SPT. Muitas das Ligas e organizações estudantis internacionais, no entanto, são membros da SPT e agor usam os congressos anuais da SPT como seu ponto de encontro internacional e tambem para fazer networking.

A SPT tem sua própria seção de estudante com uma estrutura administrativa que envolve a participação de vários países. Eles têm sido muito ativos nos congressos passados da sociedade, conduzindo seu próprio programa científico com a ajuda e participação de membros seniores da Sociedade.

A SPT está orgulhosamente envolvido em levar o grande movimento jovem para a frente, criando oportunidades robustas para sua escalada.

\section{REGISTRO DE TRAUMA}

Mudando a trajetória da vítima colossal de trauma exige estratégias preventivas informadas por vigilância de lesões e identificação de fatores de risco. A falta de dados confiáveis deixa a magnitude do problema trauma em grande parte desconhecida em muitos países de recursos limitados. Os registros de trauma prometem preencher esse vazio, captando informações importantes sobre o contínuo do cuidado dos pacientes, bem como servindo como uma ferramenta para supervisionar a qualidade do cuidado. Apesar do reconhecimento generalizado do valor dos registros de trauma e sua adoção extensa nos países desenvolvidos, apenas 50 registros em 21 países de recursos limitados estão documentados na literatura. ${ }^{9}$ Esse enorme custo do trauma nos países de baixa ou media renda precisa ser definido em sua natureza e magnitude. Ela corrobora as palavras de Margaret Chan, Diretora-Geral da OMS, "[a] verdadeira necessidade (na saúde global) é fechar as lacunas de dados, especialmente nos países de baixa e média renda, de modo que não tenhamos mais de depender fortemente na modelação estatística dos dados relativos à carga da doença"10.

A SPT, com a ajuda do Programa Internacional de Desenvolvimento de Sistemas de Trauma (ITSDP) da Virginia Commonwealth University (VCU), tem sido um pioneiro neste campo, tendo desenvolvido um Registro de
Trauma para este fim. A implementação inicial em países como Equador, Colômbia e Panamá levou à coleta de uma quantidade grande de dados e a muitos relatórios analíticos desses países. Os exemplos incluem 15 publicações (9 publicadas no Jornal da Sociedade) sobre o registro e com dados do registro da SPT coletados do "Hospital Universitário del Valle" (o maior hospital universitario da região sudeste da Colombia) e "Fundación Valle del Lili" (o maior centro de trauma de nível I da região sudeste da Colômbia). ${ }^{11-14}$

Os avanços recentes nas versões iniciais do registro tem sido impressionantes: disponibilidade de versões tanto para computadores desktop e laptop, portatil, e design escalável e compatibilidade com vários dispositivos, como telefones celulares (smartphones), iPads e outros tablets. O sistema modular e o design de banco de dados permitem uma rápida adaptação. O agrupamento lógico de elementos permite ativar e desativar elementos de acordo com o nível. O nível pré-hospitalar capta um total de 22 pontos de dados, elementos essenciais capturam 27 elementos de dados correspondentes ao número mínimo de pontos de dados necessários para suportar um programa de qualidade de trauma e o Nível 2 inclui elementos adicionais e codificação ICD10. Um registro completo tem 250 elementos de dados para a captura abrangente de dados de lesões de acordo com os vários níveis das instituições de saúde (básica, hospitais gerais, centros de referência definitiva). O ITSDP compromete-se a estabelecer, implementar e iniciar o registo de trauma nos países interessados. Seu uso está prestes a se tornar mais generalizado. Esperamos evoluir, eventualmente, a um Banco de Dados Panamericano de Trauma.

\section{COLABORAÇÃO INTERNACIONAL}

A SPT busca continuamente a colaboração com organizações e sociedades internacionais de trauma. Nos últimos 5 anos, a colaboração foi estabelecida com Trauma Association of Canada (a Associação de Trauma do Canadá), the Eastern Association for the Surgery of Trauma (a Associação Oriental para a Cirurgia do Trauma), a World Society of Emergency Surgery (Sociedade Mundial de Cirurgia de Emergência), e Trauma Center Association of America (Associação de Centros de Trauma da América). Em 2012, a SPT co-organizou o Congresso Mundial de Trauma, no Rio de Janeiro, com 3.500 participantes, e nesse mesmo ano, tornou-se membro da World Trauma Coalition (Coalizão Mundial de Trauma) e participou dos dois congressos mundiais: Frankfurt em 2014 e New Delhi em 2016. Em 2013, a SPT tornou-se membro oficial da Aliança Global da Organização Mundial da Saúde para o Cuidado dos Traumatizados. Mais impressionante foi um acordo (memorando de entendimento) com a American Association of the Surgery of Trauma 
- AAST (a Associação Americana de Cirurgia do Trauma) concluída em 2016 nas áreas de intercâmbio internacional de fellows e academicos, e reuniões clínicas internacionais via telemedicina.

Além das sociedades individuais, foram assinados múltiplos contratos (ou memorandos de entendimento) com centros acadêmicos individuais que promovem a missão da Sociedade. Estes incluem memorandos de entendimento com a Universidade de Miami para reuniões clínicas internacionais via telemedicina, a Universidade de Seattle para desenvolver uma plataforma de QI (melhoria da qualidade) on-line, VCU para desenvolver o registro de trauma da SPT, e a Universidade de Azuay e Rede Nacional Equatoriana de Pesquisa e Educação - CEDIA, para o desenvolvimento de uma plataforma eletrônica para Orientações Essenciais para o Tratamento de Trauma (EsTC) para a avaliação e verificação dos centros de trauma na Região Latina passos taticos para o desenvolvimento de ferramentas para o criação de sistemas de trauma na Região Latina. A plataforma EsTC foi testada em 2015 na Bolívia para uma avaliação de dois grandes hospitais urbanos para verificação de seus recursos e capacidades para cuidar dos traumatizados. Com pequenos ajustes, o impacto e o desenvolvimento dessas ferramentas básicas podem ser aplicados em outros países de baixa e média renda: um Memorando de Entendimento com o Instituto Médico Sri Venkateswara de Tirupathi (SVIMS) em Andhra Pradesh, no sul da Índia foi recentemente assinado para implementar cuidados de trauma e educação de trauma naquele estado.

\section{PREVENÇÃO DE TRAUMA E VIOLÊNCIA}

Essencial para a nova direção da SPT para abordar sistemas de cuidados de trauma, a prevenção de trauma tornou-se um componente integral da missão da sociedade. Palestras iniciais e esporádicas iniciais nos congressos da SPT antes de 2010 evoluíram para o desenvolvimento de um comitê de prevenção de violência e trauma em 2012 e uma bolsa de estudos de viagem em Trauma e violência em 2013. Mais notavel, um concurso dedicado à pesquisa de prevenção de trauma foi lançado em 2016, destacando 20 apresentações de pódios dos EUA, Brasil, Argentina, Venezuela, Equador e Colômbia. Em 2014, o ex-presidente Gustavo Fraga inspirou a SPT a unir-se ao movimento internacional Maio Amarelo, iniciado no Brasil, para promover a conscientização global sobre as lesões causadas pelo trânsito e a importância de sua prevenção. Além disso, em 2015 foi estabelecido um acordo (memorando de entendimento) com a Rede Nacional de Programas de Intervenção de Violência Hospitalar com sede nos EUA, para promover iniciativas internacionais e desenvolvimento de programas colaborativos. Finalmente, o discurso presidencial do M. Aboutanos em 2016 fez um chamado à ação para que a SPT desenvolva ferramentas para prevenção de trauma e violência baseada na comunidade hospitalar que incluísse 1. Diretrizes Essenciais para o desenvolvimento de programas de prevenção de trauma; 2. Banco de Dados Regional de Prevenção de Trauma integrado com o registro da SPT; 3 Guías para a pesquisa \& fundos de pesquisa de cuidados hospitalares e 4 - uma plataforma integrada para avaliações de instituicoes.

\section{EM RESUMO}

Em resumo, a SPT entrou em sua quarta década com muitas realizações, tendo sobrevivido a desafios consideráveis. Ela exemplifica a anatomia de uma sociedade bem-sucedida, criada por uma razão unificada: de fazer coisas de valor e merito, que podem ser feitas melhor juntos. A liderança da SPT aprecia esta característica distintiva. ASPT é liderado por política e estratégia, e não pela personalidade do momento. ${ }^{15}$ Ela exibe uma coerência na busca do que realmente importa, sua missão declarada. Os Presidentes da Sociedade têm consistentemente dado aos seus membros uma mensagem de unidade no meio da diversidade "ver o valor dos membros, a importância de participar da nossa reunião anual e a oportunidade de se envolver nos negócios da sociedade" - R. Coimbra, 2010; "Precisamos: ampliar a participação oficial dos Conselhos Diretivos das Sociedades de Trauma de diferentes países da SPT ... organizar as Sociedades de Trauma dos países das Américas sem um, e promover os cursos de trauma existentes, ... integrar ações e trocar experiências entre a SPT e as Sociedades de Trauma regionais sem perder a nossa identidade "- R. Poggetti, 2011; “O futuro da SPT é promissor; ... .O programa científico é de alta qualidade "- JC Puyana, 2012; “........ a Sociedade tem crescido e se tornado uma força forte e relevante no desenvolvimento de cursos educacionais, programas de prevenção, publicações e fóruns de pesquisa científica que melhoram o tratamento do trauma ......" - M.Lorenzo, 2014. Finalmente, M. Aboutanos, ex-presidente imediato da SPT, definiu para nós a próxima fronteira: “Do mesmo modo, não podemos falar de sistemas se a nossa sociedade não está envolvida na criação e no avanço das próprias ferramentas que criam o sistema, incluindo registros de trauma e cuidados assim como iniciativas de melhoria da qualidade pré-hospitalar e hospitalar...."16

A SPT percorreu um longo caminho juntamente com sua familia de sociedades: um caldeirão de diferentes raças, culturas e nacionalidades com um sonho e uma missão conjuntas. Sem dúvida, ela melhorou o atendimento ao paciente através de um intercâmbio de idéias e experiencias, ampliando o alcance da prática além do trauma e da doença crítica. Através de cursos educacionais, fellowships internacionais e programas de 
observaçaõ, envolveu seus jovens. Estimulou o interesse na nossa especialidade e acendeu chamas de curiosidade e liderança neles. Ela expos a vasta experiência com trauma da América do Sul e a habilidade cirúrgica, inata, e habilidosa de cirurgiões latino-americanos. Criou novos paradigmas aplicáveis a esses países. Iniciou estratégias de prevenção de lesões. Ela está prestes a resolver problemas de sistema de trauma.

É crucial que a SPT olhe em frente para o futuro e enfrente os desafios que inevitavelmente existem atras de cada esquina. Incerteza, mudanças e riscos virao com certeza. Lidar com a complexidade envolve a receptividade ativa, clareza, abertura e consenso. Onde é que a SPT deverá estar em uma década? Que trabalho precisa ser feito, e quem deve fazer o quê? Será que o que está sendo feito está funcionando? Existem questões pragmáticas que a nova liderança e a Sociedade precisam enfrentar e responder estrategicamente: O que é a SPT? Trata-se de uma coleção de diferentes sociedades locais, ou é uma família integrada, onde as sociedades estão dispostas a perder a sua identidade em troca de um prêmio maior? É verdadeiramente "pan-americana"? Existe a necessidade de "cortar o cordão umbelical", como alguns sugeriram? É muito presunçoso e preconceituoso pensar que uma parte da nossa sociedade seja um "cordão" de nutrição para a outra parte!

Em conclusão, propomos humildemente que é imperativo que a SPT compreenda que, neste sistema cada vez mais complexo, a ordem flui das interações, e não do controle central. Ela deveria continuar a enfatizar as pequenas ações positivas do seu corpo de membros para se beneficiar dessas interações e adaptações. Participacao ao nível global, compartilhando problemas, buscando colaboração e criando parcerias é, sem dúvida, a estratégia mais pertinente.

\section{AGRADECIMENTOS}

Os autores agradecem a:

Aos Presidentes, Comitês, e membros da SPT por sua dedicação e trabalho de amor em levar a sociedad para a frente;

Senhora Gladys Shanklin por sua coordenação excelente do escritório da SPT;

Drs Lucas, Fraga, Morales, Neira, Peitzman, Maull, Fraga, Baqueiro e Peck por suas notas da nossa história;

Dr Rodriguez por sua visão, apoio e revisão do manuscrito

E o Comité Executivo da SPT por suas revisões e sugestões valiosas.

\section{REFERÊNCIAS}

1. Marttos AC, Kuchkarian FM, Abreu-Reis P, Pereira BMT, Collet-Silva FS, Fraga GP. Enhancing trauma education worldwide through telemedicine. World J Emerg Surg. 2012; 7(Suppl 1):S4.

2. Costa CA, Garcia GD, Ginzburg E, Schulman CI, Namias N. Global Connections: Telemedicine as a tool to extend tauma education. Panam J Trauma Critical Care Emerg Surg 2013; 2(1):62-63.
3. Peck GL, Ferrada P, Joseph H, Ferrada R, Christopher D, Ordonez C, Aboutanos M, Gracias V. Can we augment the US trauma fellow's operative training? The PTS fellowship: a US surgical critical care fellow's experience in Colombia Panam J Trauma Critical Care Emerg Surg 2014;3(1):1-7.

4. Ferrada P, Ivatury RR, Spain DA, Davis KA, Aboutanos M, Fildes JJ, Scalea TM. International rotations: a valuable source to supplement operative experience for acute care surgery, trauma and surgical critical care fellows. J Trauma Acute Care Surg 2017 Jan;82(1):51-57.

5. Knuth T. Letter to the Editor. J Trauma 1993;34(6):914.

6. Ferrada P, Ferrada R, Aboutanos M, Ivatury RR. International surgical rotations: a prodigious personal and professional maturation. Am Surg 2015 May;81(5):E230-E231.

7. Ivatury R. Panamerican trauma society travelling scholarship: a cultural, clinical and surgical exchange. Panam J Trauma Crit Care Emerg Surg. 2014;3(1):v.

8. Simões RL, BermudesFA, AndradeHS, Barcelos FM, RossoniBP, Miguel GP, Fagundes CA, Fraga GP. Trauma leagues: an alternative way to teach trauma surgery to medical students. Rev Col Bras Cir 2014 Jul-Aug;41(4):297-302.

9. Boeck MA, Blair KJ, Foianini E, Perry HB, Mata LV, Aboutanos MB, Haider AH, Swaroop M. Implementation of a hospital-based trauma registry in Santa Cruz de la Sierra, Bolivia: methodology, preliminary results, and lessons learned. Panam J Trauma Crit Care Emerg Surg 2015;5(2):101-112.

10. Uribe A, Roriguez CS, Ordonez, C, Morales M, Ivatury R, Aboutanos M. Reporte del Registro de Trauma de la Sociedad Panamericana de Trauma. Un año de experiencia en dos hospitales de la ciudad de Cali. Panam J Trauma Crit Care Emerg Surg 2015;4(3):109-123.

11. Ordonez CA, Rubiano J, Badiel M, Pino LF, Minan-Arana FD, Tejada JW, Morales M, Puyana JC, Mata L, Aboutanos M, et al. Epidemiologia Del Trauma en Dos Hospitales de Primer Nivel de Atencion Del Suroccidente de Colombia. Reporte Preliminar Del Registro Internacional deTrauma de la Sociedad Panamericana de Trauma. Panam J Trauma Crit Care Emerg Surg 2014;3(1):11-15.

12. Calle-Toro JS, Ordonez C, Sanchez AI, Sanjuan J, Badiel M, Pino L, Ivatury RR, Aboutanos M. Epidemiologia de Lesiones Relacionadas con Colisiones Vehiculos Motorizados en dos Centros de Referencia del Suroccidente Colombiano. Reporte del Registro Internacional de Trauma de la Sociedad P. Panam J Trauma Crit Care Emerg Surg 2014;3(1):16-22.

13. Rodriguez CS, Uribe A, Ordonez C, Morales M, Ivatury R, Aboutnaos M. Reporte de la Tendencia del: Trauma Pediátrico en dos Hospitales de Cali en el 2012. Panam J Trauma Crit Care Emerg Surg 2015;4(3):124-135.

14. Ordoñez CA, Morales M, Rojas-MirquezJC, Bonilla-Escobar FJ, Badiel M, Miñán Arana F, González A, Pino LF, Uribe-Gómez A, Herrera MA, et al. Trauma registry of the Pan-American Trauma Society: one year of experience in two hospitals in southwest Colombia. Colomb Med (Cali) 2016 Sep 30;47(3):148-154.

15. Tecker GH. https://www.asaecenter.org/resources/.../sustaining-association success that matters. American Society of Association Executives website. Available from: https:// www.asaecenter.org/resources/articles/an_magazine/2011/ december/Sustaining-association-success-that-matters. Accessed November 11, 2015.

16. Aboutanos M. President's message. Available from: http:// www.panamtrauma.org/president-message. Accessed December 31, 2016. 